\title{
Fluoride Exposure Induces Inhibition of Sodium/Iodide Symporter (NIS) Contributing to Impaired Iodine Absorption and Iodine Deficiency: Molecular Mechanisms of Inhibition and Implications for Public Health
}

\author{
Declan Timothy Waugh \\ EnviroManagement Services, 11 Riverview, Doherty's Rd, Bandon, Co. Cork P72 YF10, Ireland; \\ declan@enviro.ie; Tel.: +353-23-884-1933
}

Received: 19 February 2019; Accepted: 21 March 2019; Published: 26 March 2019

\begin{abstract}
The sodium iodide symporter (NIS) is the plasma membrane glycoprotein that mediates active iodide transport in the thyroid and other tissues, such as the salivary, gastric mucosa, rectal mucosa, bronchial mucosa, placenta and mammary glands. In the thyroid, NIS mediates the uptake and accumulation of iodine and its activity is crucial for the development of the central nervous system and disease prevention. Since the discovery of NIS in 1996, research has further shown that NIS functionality and iodine transport is dependent on the activity of the sodium potassium activated adenosine $5^{\prime}$-triphosphatase pump ( $\mathrm{Na}+, \mathrm{K}+$-ATPase). In this article, I review the molecular mechanisms by which F inhibits NIS expression and functionality which in turn contributes to impaired iodide absorption, diminished iodide-concentrating ability and iodine deficiency disorders. I discuss how NIS expression and activity is inhibited by thyroglobulin (Tg), tumour necrosis factor alpha (TNF- $\alpha$ ), transforming growth factor beta 1 (TGF- $\beta 1$ ), interleukin 6 (IL-6) and Interleukin 1 beta (IL-1 $\beta$ ), interferon- $\gamma$ (IFN- $\gamma$ ), insulin like growth factor 1 (IGF-1) and phosphoinositide 3-kinase (PI3K) and how fluoride upregulates expression and activity of these biomarkers. I further describe the crucial role of prolactin and megalin in regulation of NIS expression and iodine homeostasis and the effect of fluoride in down regulating prolactin and megalin expression. Among many other issues, I discuss the potential conflict between public health policies such as water fluoridation and its contribution to iodine deficiency, neurodevelopmental and pathological disorders. Further studies are warranted to examine these associations.
\end{abstract}

Keywords: fluoride; iodine; NIS; Na+, K+-ATPase; TNF- $\alpha$; TGF- $\beta 1$; IL-6 and IL-1 $\beta$; IFN- $\gamma$; IGF-1; PI3K; megalin; prolactin

\section{Introduction}

Iodine is a vital micronutrient required at all stages of life; foetal life and early childhood being the most critical phases of requirement. Iodine, as its water-soluble iodide ion is the rate-limiting substrate for the synthesis of thyroid hormones (THs): thyroxin (T4) and tri-iodothyronine (T3), which are necessary for the control of cellular metabolism, growth and development of the body structures, neuronal function and development [1,2]. The T4 and T3, which are iodinated molecules of tyrosine, an amino acid that is synthesized in the body from phenylalanine, that is an essential amino acid, regulate oxidative enzymes and hence affect calorigenesis, thermoregulation, and intermediary metabolism. In addition to regulating carbohydrate metabolism these hormones also stimulate protein synthesis [3]. Iodine deficiency occurs when iodine intake falls below recommended levels and the 
thyroid gland is no longer able to synthesize sufficient amounts of thyroid hormone. The resulting hypothyroidism can occur at any stage of life, but the most devastating consequences of iodine deficiency take place during foetal development and childhood, with stillbirth, miscarriages, poor growth, and cognitive impairment. Iodine deficiency remains a major public health problem worldwide and the world's greatest single cause of preventable brain damage [4].

Urinary excretion of iodine is the diagnostic indicator used to determine the nutritional state of iodine in the population, using the established references by WHO. Iodine deficiency is defined by the $\mathrm{WHO}$ as a population median urinary iodine concentration (UIC) that falls below $100 \mu \mathrm{g} / \mathrm{L}$, while a median UIC of 50-99, 20-49 and $<20 \mu \mathrm{g} / \mathrm{L}$ indicates mild, moderate, and severe iodine deficiency, respectively. In pregnancy the recommended threshold for UIC is $150 \mu \mathrm{g} / \mathrm{L}$ [5]. In addition to UIC, other measures of iodine status include thyroid volume, thyrotropin (TSH), triiodothyronine (T3), and thyroxine (T4). In 2004, it was estimated that of the two billion people around the world at risk of iodine deficiency, 20 percent live in Europe, Eastern and Western Europe being both affected [6]. In 2015, an estimated 12 countries have excessive iodine intake, 116 have adequate iodine nutrition and 25 remain iodine deficient $[7,8]$.

While it is acknowledged that iodine deficiency increases the risk of fluoride $(\mathrm{F})$ induced toxicity on thyroid function [9], it has also been reported that dietary iodine absorption and incorporation is reduced by F [10-16]. Indeed, in 2002, the Scientific Committee on Food, the main committee providing the European Commission with scientific advice on food safety, reported that dietary iodine absorption and incorporation is reduced by $\mathrm{F}$ in food and water [11]. Yang et al. observed that thyroid iodine uptake was markedly reduced in children when urinary F levels were approximately $2.0 \mathrm{mg} / \mathrm{L}$. In this study, higher F exposure was also associated with dental fluorosis, higher serum TSH and lower IQ than age matched controls from a low F area [15]. Susheela et al. reported that elevated $\mathrm{F}$ uptake may cause iodine deficiency in fluorotic individuals, even when they reside in non-iodine deficient areas [12]. More recently, Sarkar and Pal suggested that F intoxication may contribute to iodine deficiency by inhibition of absorption of the iodine in humans as well as contributing to decreased retention of iodine through the interaction of F. [13]. A recent cross-sectional study conducted in Canada, which utilized weighted population-based data from Cycle 3 (2012-2013) of the Canadian Health Measure Survey (CHMS), found that UIC's were lower in fluoridated than non-fluoridated communities. Moreover, iodine deficient individuals were found to have higher urinary F concentrations compared with the non-iodine deficient group [14]. This finding is supported by epidemiological data from China [17], which found that higher urinary F excretion was associated with significantly lower UIC in children. Further studies conducted in China, also found that excessive $\mathrm{F}$ exposure inhibited thyroid iodine uptake in children [10]. Similar effects were observed in a Russian study examining the effects of occupation exposure to $\mathrm{F}$ among subjects with signs of chronic fluorosis [18]. Consistent with these findings, a recent all Ireland study which measured iodine status in adolescent girls throughout the island of Ireland; which includes the Republic of Ireland (RoI) and Northern Ireland (NI), found that median UIC's were significantly lower in adolescent girls in all participating locations in the RoI compared to NI. In addition, the percentage of adolescent girls with moderate to severe iodine deficiency $(<50 \mu \mathrm{g} / \mathrm{L})$ were $2-4$-fold higher in the RoI compared to NI [19]. In examining this data, it is of fundamental importance to understand that approximately $84 \%$ of all households in the RoI have fluoridated water supplies [20], while drinking water is non-fluoridated in NI. Thus, the population in the RoI have higher exposure to F than NI. Therefore, this data validates the findings of the aforementioned studies suggesting that $\mathrm{F}$ exposure directly affects the bioavailability of iodine in humans.

It is important to be aware that chronic iodine deficiency increases the TSH concentration and produces a thyroid hormone pattern consistent with subclinical hypothyroidism [21]. Interestingly, in recent decades there has been a remarkably decline in UICs reported in the United States [22], Australia [23], New Zealand [24-26] and the RoI [27], leading one to postulate whether water fluoridation, which is widely practised in these countries, may be contributing to iodine deficient 
states and subclinical and overt hypothyroidism in the population. Indeed, recent studies conducted in England and Iran support this hypothesis [28,29]. Previous animal models of F-induced hypothyroidism have further demonstrated that excessive intake of $\mathrm{F}$ in drinking water and prenatal $\mathrm{F}$ intoxication induces hypothyroidism in offspring [30-32]. In another study, Ahmed et al. showed that the hypothyroid status during pregnancy and lactation produced inhibitory effects on monoamines, acetylcholinesterase (AchE) and ATPases and excitatory actions on $\gamma$-Aminobutyric acid (GABA) in different brain regions of the offspring. The authors reported that the thyroid gland of offspring of hypothyroid group exhibited histopathological changes as luminal obliteration of follicles, hyperplasia, fibroblastic proliferation and some degenerative changes [33]. Taken together, these findings suggest that $\mathrm{F}$ induced maternal hypothyroidism may cause a number of biochemical disturbances in different brain regions of offspring that may lead to a pathophysiological state.

Evidence from epidemiological studies also suggest that the combination of iodine deficiency and $\mathrm{F}$ exposure result in higher risk of developmental disorders, including impaired cognitive function in children [34-36]. Another experimental study found that excessive maternal exposure to F combined with a low iodine diet resulted in significantly increased oxidative stress in the brain of offspring compared to controls or animals exposed to $\mathrm{F}$ without iodine deficiency. Moreover, the authors of this study concluded that high $\mathrm{F}$ and low iodine intake resulted in significantly increased neurotoxic histopathological changes in the brain of offspring compared to high $\mathrm{F}$ alone, indicating that excessive $\mathrm{F}$ exposure and iodine deficiency interact synergistically to induce brain damage [37]. Consistent with these findings experimental research has also found that the combination of high $\mathrm{F}$ and low iodine has a greater negative effect on learning-memory of offspring rats than treatment with either low iodine or high $\mathrm{F}$ alone [38]. Further animal studies found that increased $\mathrm{F}$ intake combined with iodine deficiency can decrease serum thyroxine (T4) and triiodothyronine (T3) levels, as well as increase the F content and toxic effects of fluorosis in teeth and bones [39]. Experimental studies have also demonstrated that excess $\mathrm{F}$ intake causes DNA damage in thyroid cells comparable to that observed with iodine deficiency and that the effect was enhanced when F was given with a low iodine diet [40]. Another study with female mice and their lactating pups found that exposure to $F$ resulted in a significant decrease in thyroid iodine content in pups and mothers along with hypertrophy of their thyroid glands. Notably, in this study, the authors reported that when F ion was eliminated from the mothers' drinking water essentially complete recovery was observed in thyroid iodine content [31]. The potential of $\mathrm{F}$ to impair iodine stores has also observed in studies with cows, sheep and rodents resulting in significant reduced protein bound iodine in animals with chronic fluorosis compared to healthy controls from non-fluorotic areas [39,41-43].

As elucidated earlier, while studies among populations with different genetic variations in different geographic regions consistently show that $\mathrm{F}$ intake contributes to lower bioavailability of iodine, the molecular mechanisms by which this phenomenon occurs have not been fully defined. I recently revealed the molecular mechanisms by which $\mathrm{F}$ inhibits $\mathrm{Na}+, \mathrm{K}+$-ATPase activity and hypothesized that inhibition of $\mathrm{Na}+, \mathrm{K}+$-ATPase activity may play a crucial role in contributing to impaired iodine absorption and iodine deficient states. In this current study, I elucidate the role F plays in contributing to impaired iodine absorption focusing on the Na+/I- symporter (NIS). Here, I focus on the molecular mechanisms by which F inhibits NIS functionality and gene expression. These findings provide unprecedented insights into the molecular mechanisms by which $\mathrm{F}$ inhibits iodine uptake, transport and reabsorption, and provide a basis for minimising or preventing the risk of adverse health outcomes associated with iodine deficiency.

\subsection{Dietary Sources of Iodine}

Oceans are the world's main repositories of iodine and very little of Earth's iodine is actually found in the soil. Sea water contains $50 \mu \mathrm{g}$ iodine/L. In the ocean, iodide is converted into elemental iodine, a volatile form that enters the environment as sea spray or volatile gases. Molecular iodine is also released from seaweed. After emission and due to photolytic dissociation iodine from the ocean is 
transferred to the atmosphere and returned to the land through rain and to a lesser extent snow [44-51]. Hence, it has been reported that coastal regions of the world are generally richer in iodine content than the soils further inland [52] and proximity to the sea, particularly coastal areas abundant with seaweed may contribute to dietary iodine intake through respiration [53,54].

The iodide content of foods and total diets differs depending on geochemical, soil, and cultural conditions. Notwithstanding the apparent contribution of marine atmospheric sources, the major natural sources of iodine are iodine saltwater fish and seafood because of their ability to concentrate iodine from seawater [52]. In certain countries such as Japan, the consumption of seaweed provides a significant source of dietary iodine [55]. Milk and dairy products are also a rich source of iodine, particularly in Ireland, the UK, Europe and North America where animal fodder is fortified with iodine and iodine-based disinfectants may be used in milking [56-60]. Other sources are eggs, freshwater fish, poultry and meat, fruits, legumes and vegetables. Generally common food sources provide 3-80 $\mathrm{mg} /$ serving [61,62]. The iodine content in drinking water can vary significantly depending on whether it is sourced from groundwater or natural surface waters, geology, aquifer characteristics and distance from sea. In certain geographic locations high iodine content in drinking water may also provide a major direct source of iodine intake, which may determine regional variations in iodine intake levels $[63,64]$. The iodine content in rivers can also vary depending on receiving effluent from urban areas [65]. Iodized salt provides another major source of iodine. Salt ionization was introduced in the USA, Australia and New Zealand in the 1920s and iodization policies have been increasingly used worldwide in recent decades to supplement dietary intake. The greatest access to salt iodization occurs in the World Health Organization (WHO) regions of the Western Pacific and the Americas, and the least access for those residing in the Eastern Mediterranean and Europe [4]. Since the 1950s the proportion of U.S. households which use only iodized salt has remained stable at 70-76\% [66]. The intake of processed food containing iodized salt, calcium iodate, potassium iodate or cuprous iodide also increase the iodine intake. Non-food sources of iodine include iodine-containing medication, topical medicines, antiseptics, mineral dietary supplements, tablets or capsules of seaweed-based dietary supplements and kelp tablets as dietary supplements.

\subsection{Metabolism of Iodine}

Iodide is metabolized in the human body through a series of stages involving the hypothalamus, pituitary, thyroid gland and blood. The hypothalamus releases thyrotropin-releasing hormone (TRH) into circulation which stimulates thyrotrophs of the anterior pituitary to secrete TSH. regulates the secretion of thyroid-stimulating hormone (TSH) in the pituitary gland. In turn, TSH stimulates the thyroid follicular cells to release T4 and T3. When T4 is released into circulation, it can be converted to T3 through the process of de-iodination. TSH also stimulates the expression of thyroglobulin ( $\mathrm{Tg}$ ) and promotes the rapid internalization of $\mathrm{Tg}$ by thyrocytes. Altered regulation or defects in any of these steps can affect thyroid hormone synthesis and secretion [67]. Consumed iodine is absorbed as iodide in the intestines through the sodium iodide symporter (NIS) [68] and transferred into circulation. In contrast, the salivary glands and stomach take iodide from the bloodstream and release it into gastrointestinal tract for re-absorption through intestine [69].

Thyroid gland plays a central role in the metabolism of iodine. The gland comprises multiple follicles lined by follicular cells resting on a basement membrane. The follicles are filled by a clear viscous material called colloid. The colloid contains a glycoprotein called thyroglobulin. Iodine trapping is the first step in the metabolism of iodine [70]. Iodine transport by NIS from the bloodstream into thyrocytes through the basal surface is one of the most important events in thyroid hormone synthesis. In the thyroid, NIS concentrates iodide to a level that is 20 to 50 times that in plasma [71,72]. NIS also mediates the transport of iodine across cellular membranes and uptake of iodide into salivary, gastric mucosa, rectal mucosa, bronchial mucosa, placenta and mammary glands, through which iodide is delivered to the new-born for proper development [68,73-77]. Moreover, NIS regulates iodine availability in the thyroid, necessary for Tg iodination and T4 and T3 synthesis [78]. NIS functionality 
and iodine transport is dependent on the activity of the sodium potassium activated adenosine $5^{\prime}$-triphosphatase pump (Na+, K+-ATPase), or sodium pump [78]. Synthesis of T4, the primary form of TH released by the thyroid gland, consists of two sequential steps: iodination of selected tyrosines of $\mathrm{Tg}$, and coupling of two doubly iodinated tyrosines within $\mathrm{Tg}$ to produce $\mathrm{T} 4$. Thus, $\mathrm{TH}$ synthesis relies on iodide availability [78]. To minimize the deleterious effects of iodide deficiency, iodinated $\mathrm{Tg}$ is stored extracellularly [78] and this process is mediated by megalin [79-81]. In the thyroid, megalin is expressed on the apical surface of thyrocytes, where it binds and internalizes $\mathrm{Tg}$, after which $\mathrm{Tg}$ is transported across cells by transcytosis. Transcytosis is the major route by which $\mathrm{Tg}$ reaches the circulation. Thus, megalin plays an essential role in transcytosis and points to a major role of megalin in thyroid homeostasis with possible implications in thyroid diseases [79].

Because $\mathrm{Tg}$ is the molecular scaffold for TH synthesis and iodide storage, it is important to note that $\mathrm{Tg}$ molecules internalized by megalin are not reduced or degraded in the lysosomal pathway which otherwise lead to the formation of T4 and T3 [80]. This extracellularly storage serves as the body's primary reservoir for iodide storage [78]. Thus, megalin plays a crucial role in regulating iodine stores and the thyroid exchangeable hormonal iodine pool. During periods of low iodine intake or deficiency TSH secretion is augmented which stimulates Tg reabsorption by thyrocytes, $\mathrm{Tg}$ degradation and the release of iodine for the synthesis of TH. [82,83]. It is also known that albumin is iodinated in the thyroid gland and when albumin is elevated in blood a high protein bound iodine value can be recorded [84].

The thyroid is estimated to use $60-80 \mu \mathrm{g}$ of iodide daily to produce its customary output of thyroid hormones [85]. About a quarter of the daily requirement of iodine is acquired from recycling endogenous iodide and the rest is acquired from the diet [86]. In healthy adults, the absorption of iodide is greater than $90 \%$ [87]. In conditions of adequate iodine supply, no more than $10 \%$ of absorbed iodine is taken up by the thyroid. In chronic iodine deficiency, this fraction can exceed $80 \%$ [88-90]. In most individuals, if iodine intake falls below approximately $100 \mu \mathrm{g} / \mathrm{d}$, TSH secretion is augmented which increases plasma inorganic iodide clearance by the thyroid through stimulation of NIS expression. As a greater fraction of circulating iodine is cleared by the thyroid, there is a progressive reduction in renal iodide excretion. [91]. Chronic iodine deficiency increases the TSH concentration and produces a thyroid hormone pattern consistent with subclinical hypothyroidism [21]. Iodine deficient individuals typically demonstrate a variable elevated TSH, with a low-normal range of serum T4, and a normal or high-normal T3 [91].

In pregnancy the iodine requirement is increased due to an increase in maternal T4 production to maintain maternal euthyroidism and transfer thyroid hormone to the foetus early in the first trimester, before the foetal thyroid is functioning; iodine transfer to the foetus, particularly in later gestation; and an increase in renal iodine clearance [92]. Foetal thyroid activity depends entirely on the availability of iodine transferred from maternal circulation [93]. During lactation, the mammary gland concentrates iodine and secretes it into breast milk to provide for the new-born, thereby supplementing the iodine pool in infants for the synthesize TH [94]. The infant also needs a supply of iodine for normal thyroid activity, vital for brain development in the first 2 years of life. The supply of iodine to the neonate and infant comes exclusively from breast or formula milk in the first 6 months of life and from milk/formula and complementary foods thereafter [94]. Thus, the iodine requirement of a woman who is fully breastfeeding her infant is likely to be higher than that during pregnancy [91]. The lactating breast can concentrate iodide to a similar degree as that seen in the thyroid, producing milk with an iodine concentration of 20-700 $\mu \mathrm{g} / \mathrm{L}$ [95].

\section{Molecular Mechanisms of Fluoride Inhibition of Iodine Homeostasis}

The molecular mechanisms of $\mathrm{F}$ action underlying disturbed iodine homeostasis are complex and require a detailed knowledge of regulation of biological processes. These effects derive from two interlinked mechanisms. As I previously elucidated, $\mathrm{F}$ acts to inhibit $\mathrm{Na}+, \mathrm{K}+-\mathrm{ATPase}$ activity, which is essential for regulating NIS functionality $[96,97]$. NIS expression and functionality in turn 
is required for the efficient absorption of iodide in the intestines, and the transportation and uptake of iodide into the thyroid gland. As previously noted, NIS also mediates the transport of iodine across cellular membranes and uptake of iodine into salivary, gastric mucosa, rectal mucosa, bronchial mucosa, placenta and mammary glands. However, current evidence also suggests that $\mathrm{F}$ acts to inhibit NIS mRNA expression through several biological mechanisms as outlined below.

\subsection{Molecular Mechanisms of F Inhibition of $\mathrm{Na}+/ \mathrm{K}+-$ ATPase Activity}

As a first step to elucidate the basis for the decrease in iodine bioavailability observed in countries with fluoridation programmes, it is of fundamental importance to understand that NIS functionality requires $\mathrm{Na}+, \mathrm{K}+-\mathrm{ATP} a s e$ activity. As previously mentioned, the molecular mechanisms of $\mathrm{F}$ inhibition of $\mathrm{Na}+, \mathrm{K}+-\mathrm{ATP} a \mathrm{se}$ activity have recently been comprehensively defined [98]. In summary it has been shown that activation of PKC, cAMP, cGMP, NO, Pi, PLA2, AA, PGE2, dopamine, glucose and PTH and the formation of AGEs inhibit $\mathrm{Na}+, \mathrm{K}+$-ATPase activity and that $\mathrm{F}$ acts to upregulate the formation of these biomarkers. In addition, it has been elucidated that $\mathrm{F}$ inhibition of $\mathrm{CT}$ contributes to impaired $\mathrm{Na}+, \mathrm{K}+$-ATPase functionality [96].

\subsection{Deciphering the Molecular Mechanisms of F Inhibition of NIS Expression and Activity}

Several cytokines have been identified to inhibit NIS mRNA expression and activity including tumour necrosis factor alpha (TNF- $\alpha$ ), transforming growth factor beta 1 (TGF- $\beta 1$ ) [97-102], IL-6 and IL-1 $\beta$ [103], and interferon- $\gamma$ (IFN- $\gamma$ ) [104]. It has also been documented that the hormone, insulin like growth factor 1 (IGF-1) [105], and enzyme phosphoinositide 3-kinase (PI3K), inhibit NIS mRNA expression in thyroid cells [106]. Several studies have shown that the protein thyroglobulin (Tg), decreases NIS gene [107-113] and vascular endothelial growth factor (VEGF) gene expression [109], thereby reducing iodine uptake. Tg also supresses gene expression of TSH receptor (TSHR) $[108,112,113]$ and thyroid transcription factor-1 (TTF-1) $[108,113]$. Previous studies have also shown that TTF-1 upregulates NIS gene expression [114-116]. Moreover, TSHR is regulated only by TTF-1 [108], thus, loss of TTF-1 can also result in impaired TSHR functionality. Furthermore, loss of TSHR abundance or function can result in partial TSH resistance, increased serum TSH levels and hypothyroidism [117]. Inactivation of TSHR receptor is also associated with premature birth and low birth weight babies [118]. Conversely, prolactin (PRL) has been found to elevate NIS mRNA and protein levels [119-121]. As there are no studies as yet specifically addressing F inhibition of NIS activity, evidence was sought from published literature including human, animal and in vitro studies to examine how $\mathrm{F}$ interacted with each of the aforementioned biological pathways identified as inhibitors of NIS gene expression or activity. A schematic representation of the role of NIS in iodine transport and the molecular mechanisms of NIS inhibition is provided in Figure 1. In the following section, I summarise the studies documenting the effect of F on TNF- $\alpha$, TGF- $\beta 1$ ) IL- 6 and IL- $1 \beta$, IFN- $\gamma$, IGF-1, PI3K and Tg.

Though the underlying molecular mechanisms remain elusive, previous studies have shown that F activates IGF1 signalling [122], resulting in significantly increased serum IGF-1 levels [123]. $F$ has also been found to enhance the mitogenic activities of IGF-1 action on bone cells [124,125]. However, it is important to note that prostaglandin E2 (PGE2) and TNF- $\alpha$ have been shown to induce IGF-1 production [126-130]. PGE2 acts as a positive stimulus for IGF-I synthesis through a cyclic AMP/PKA pathway and TNF- $\alpha$ stimulated IGF-1 synthesis via the mitogen-activated protein (MAP) kinase pathway [130]. Of fundamental importance, in vitro experiments using human blood cells have consistently demonstrated that $\mathrm{F}$ in micromolar concentrations of $1-10 \mu \mathrm{M}$ significantly increased the synthesis of cAMP and the synthesis of PGE2 in a dose dependent manner [131-133]. Most recently, Gutowska et al. demonstrated that F at $3 \mu \mathrm{M}$ increased PGE2 synthesis by $42 \%$ in macrophages compared to negative controls [133]. Several in vitro, in vivo and human studies have also demonstrated that $F$ induces upregulation of IL- 6 and IL-1 $\beta$ mRNA expression resulting in enhanced activity [134-138]. In addition, F exposure has been found to upregulate TNF- $\alpha$ expression 
in human and animal studies [134-139], and it has also been demonstrated in vivo and in vitro that F induces upregulation of PI3K mRNA and protein levels [140-144].

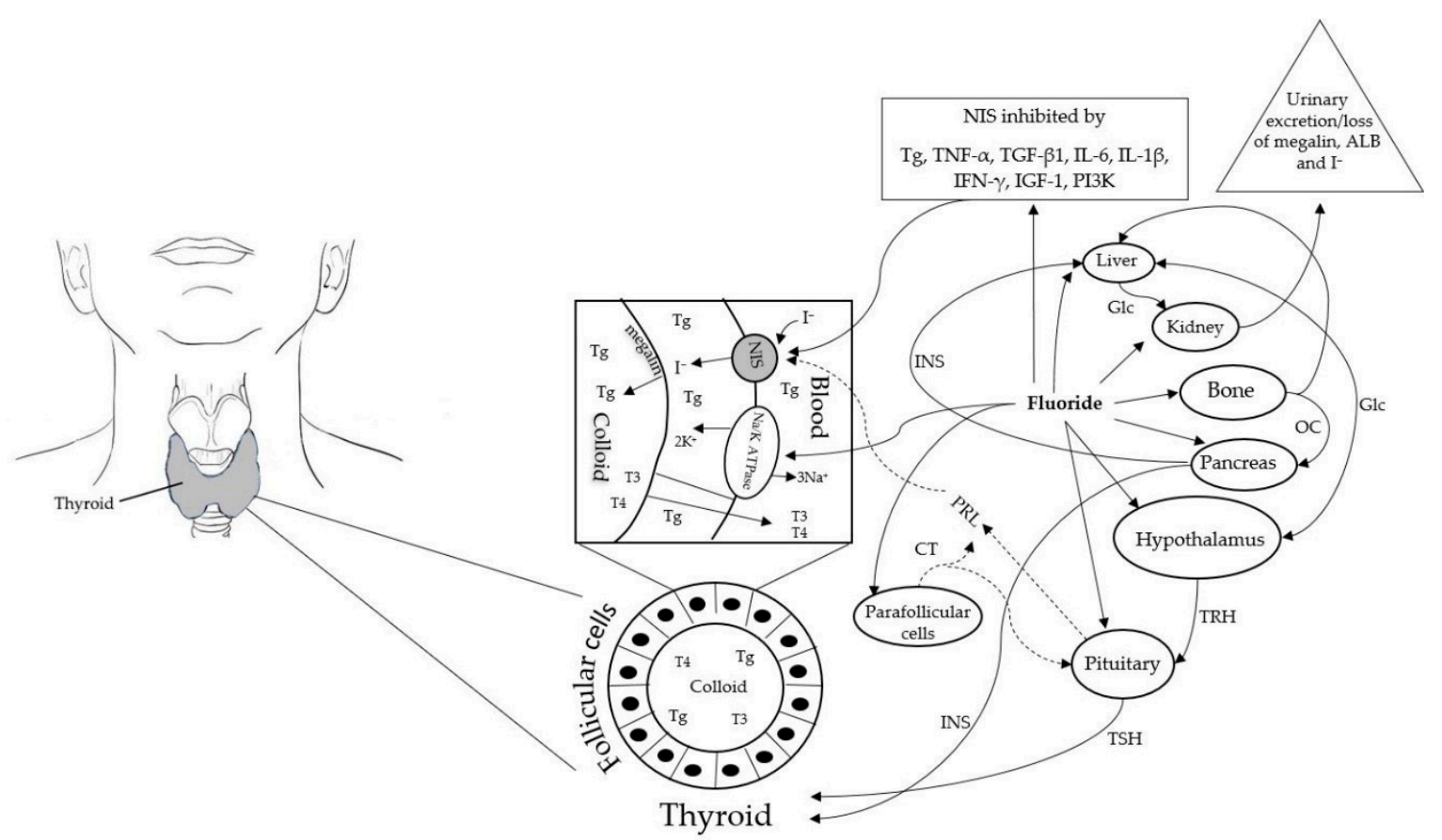

Figure 1. Schematic representation of the role of NIS and $\mathrm{Na}+, \mathrm{K}+-\mathrm{ATP}$ ase in normal thyroid follicular cells showing the key aspects of iodine transport, thyroid hormone synthesis and molecular mechanisms of inhibition of NIS by fluoride. Abbreviations: NIS: Sodium/Iodide Symporter; ALD: Albumin; CT: Calcitonin; Glc: Glucose; I-: Iodide; INS: Insulin; IGF-1; Insulin like growth factor 1; IL-6: Interleukin 6; IL-1 $\beta$ : Interleukin 1 beta; IFN- $\gamma$ : Interferon- $\gamma$; OC: Osteocalcin; PRL: Prolactin; PI3L: Phosphoinositide 3-kinase; Tg: Thyroglobulin; THR: Thyrotropin-releasing hormone; TSH: Thyroid-stimulating hormone; T4: Thyroxin; T3: Tri-iodothyronine.

Studies have also shown that F significantly increases IFN- $\gamma$ mRNA expression and serum levels [145]. Notably, Lv et al. observed that F induced IFN $\gamma$ signalling activates osteoclasts and aggravates oestrogen deficiency inducing osteoporosis [145]. It has also been reported that TGF- $\beta 1$ plays an important role in fluorosis and increased levels of TGF- $\beta 1$ have been suggested as an important marker in the evaluation of the pathological action of $F$ in bone tissue $[146,147]$. In vivo and in vitro experimental studies of fluorosis have shown that $F$ upregulates TGF- $\beta 1$ protein and mRNA expression in bone cells [146,148-150]. Importantly, Calcitonin (CT), a hormone that is secreted by parafollicular cells of the thyroid gland has been found to be a potent stimulator of TGF- $\beta 1$ protein synthesis as well as TGF- $\beta 1$ mRNA expression. [151]. A large body of evidence from epidemiological studies has demonstrated that $\mathrm{F}$ is a potent inducer of CT expression in humans [152-157]. Of fundamental importance is the research by Chen and associates in providing a biological dose-exposure response relationship for $\mathrm{F}$ exposure on CT expression at relatively low intakes. Notably, in this study, it was demonstrated that differential expression of CT occurs when urinary F levels exceeded $0.38 \mathrm{mg} / \mathrm{L}$ [155].

As previously noted, PRL has been found elevate NIS mRNA and protein levels. It is important to note therefore that in vivo and in vitro studies with animals [158] as well as human studies $[159,160]$ have shown that F inhibits PRL secretion. Moreover, the inhibitory effect was found to be significantly more prevalent in females than males [160]. Notably, among adults with dental fluorosis Murugan and Subramanian observed that in addition to an abrupt reduction in serum concentrations of PLC, subjects with dental fluorosis also had significantly lower levels of T3 and T4 and significantly higher levels of TSH compared to subjects residing in the same community without dental fluorosis [159]. In another study, Ortiz-Pérez et al. found that serum PRL levels were significantly lower in adult 
males occupationally exposed to F with a mean urinary F level of $3.2 \mathrm{mg} / \mathrm{L}$ (range 2.9-3.4 mg/L) compared to males residing in a low F community where the mean urinary F level was $1.6 \mathrm{mg} / \mathrm{L}$ (range 1.3-1.9 mg/L) [160]. While F has been found to inhibit PRL, the molecular mechanisms behind this of inhibition remain unclear. However, it is important to note that CT is a PRL-inhibiting hormone [151,161-164]. As previously discussed, $\mathrm{F}$ has been found to be a potent inducer of CT expression in humans [152-157]. These findings suggest a plausible mechanism whereby F exposure inhibits NIS expression through F stimulation of CT which acts to inhibit PRL secretion.

As previously elucidated, $\mathrm{Tg}$ has been found to play a crucial role in downregulating NIS expression. There is robust evidence from epidemiological studies conducted in different geographic regions to show that $\mathrm{F}$ exposure increases TSH levels in humans $[12,15,18,29,35,165-178]$. Since TSH stimulates thyroid follicular cells to produce $\mathrm{Tg}[179,180]$; serum $\mathrm{Tg}$ concentrations are typically higher in individuals with a raised TSH or primary hypothyroidism [181]. TSH dependant elevation of serum $\mathrm{Tg}$ has also been observed in subclinical hypothyroidism in patients with chronic kidney disease [182]. Interestingly, evidence suggests that serum Tg levels are higher in females than males [183-185], and increase with increasing levels of TSH and decreasing urinary iodine concentration [185]. However, it is also important to note that NIS expression is inhibited by oestradiol, the major female sex hormone [186]. This may also explain why thyroid diseases predominantly affect women; their incidence is 5-20 times higher in women than in men [187]. Of note, oestrogen, the primary female sex hormone suppresses IFN $\gamma$ [145]. In menopause oestrogen levels decrease, as oestrogen decrease IFN $\gamma$ expression increases, which elucidates why the incidence of hypothyroidism increases significantly in postmenopausal women [188-191]. However, it is important to note that serum F levels have also been shown to increase significantly in women post menopause [192-194]. Husdan et al. reported that the rate of change of serum ionic $F$ concentration with age for women was observed to be twice that for men over 45 years of age. It was suggested that the greater rate of increase noted in females was probably due to the enhanced release of $\mathrm{F}$ from bone observed after the menopause [192]. These results indicate that elevation of plasma F levels post menopause may be involved in elevating TSH as well as $\mathrm{Tg}$ and contributing to the increased NIS inhibition and increased prevalence of hypothyroidism in postmenopausal women.

It is important to note, that $\mathrm{Tg}$ gene expression is regulated by insulin and insulin like growth factor 1 (IGF-1) [195]. Moreover, the presence of insulin is necessary for TSH inhibition of TTF-1 gene expression [196]. Accumulating evidence has shown that osteocalcin, which is specifically expressed in osteoblasts and secreted into the circulation, regulates insulin secretion by stimulating insulin expression in pancreas [197-203], as well as by indirectly stimulating insulin through increasing the secretion of glucagon-like peptide-1 (GLP-1), an incretin released by intestinal endocrine cells [204,205]. Importantly, several epidemiological studies have also confirmed that $\mathrm{F}$ exposure significantly increases OC expression in humans $[154,155,206-210]$. A significant effect of F on OC expression has been found to occur in adults at serum F levels of $1.0 \mu \mathrm{M}$ [154] or when urinary F levels exceed $0.62 \mathrm{mg} / \mathrm{L}$ in adolescent children [155]. Consistent with this data, several in-vivo studies have reported that chronic F exposure enhances plasma insulin levels and promotes insulin resistance in rodents [211-215]. A similar association has also been found in humans chronically exposed to F [216]. As previously noted, studies have also shown that F activates IGF1 signalling and enhances the mitogenic activities of IGF-1 action on bone cells [122-125].

Finally, it is important to mention one other protein, megalin. As previously elucidated megalin regulates iodine stores and the thyroid exchangeable hormonal iodine pool in humans by regulating extracellularly storage of iodine in $\mathrm{Tg}$, which serves as the body's primary reservoir for iodide storage. Furthermore, $\mathrm{Na}+, \mathrm{K}+$-ATPase activity is required for NIS to transport iodide into $\mathrm{Tg}$ for iodide accumulation and thyroid hormone synthesis in the thyroid gland. As previously noted, $\mathrm{Na}+$, $\mathrm{K}+$-ATPase is inhibited by $\mathrm{F}$ [96]. Thus, inhibition of megalin or $\mathrm{Na}+, \mathrm{K}+-\mathrm{ATPase}$ can lead to depletion of iodine stores and iodine deficiency. While there are no studies in literature examining the relationship between $\mathrm{F}$ exposure in humans and megalin expression, recently it has been found in animal models 
that chronic F exposure inhibits megalin expression [217]. It has been observed in animal studies that a decrease in megalin expression leads to a decrease in proximal tubule albumin (ALB) reabsorption [218], leading to enhanced urinary excretion. Further studies have found that megalin expression is inhibited by elevated glucose levels $[219,220]$. Importantly, a large number of human and animal studies have demonstrated that $\mathrm{F}$ exposure can induce hyperglycaemia [218,221-234]. Consistent with this, the U.S. National Research Council (NRC) reported that the conclusions from available studies is that sufficient F exposure appears to bring about increases in blood glucose or impaired glucose tolerance in some individuals and the increase the severity of some types of diabetes [9]. Therefore, evidence suggests that the ability to $\mathrm{F}$ to promote hyperglycaemia may lead to inhibition of megalin expression. Further studies are required confirm this association in humans.

Moreover, in addition to $\mathrm{Tg}$, it is also known that ALB is iodinated in the thyroid gland and when ALB is elevated in blood a high protein bound iodine value can be recorded [84] and in cases of hypoalbuminemia (low levels of ALB in blood) serum iodine levels can be reduced $[235,236]$. These observations provide evidence of the role of ALB in modulating the iodine pool in humans. In this regard, it is long known that one of the clinical symptoms of $\mathrm{F}$ intoxication is inflammation of the kidneys, resulting in higher ALB in urine [237]. As previously described, inhibition of megalin expression can also lead to enhanced urinary excretion by impairing proximal tubule ALB reabsorption, which further leads to lower ALB in systemic circulation. Consistent with these findings, a recent cross-sectional study reported an association between $\mathrm{F}$ exposure and increased urinary excretion of ALB in Mexican adults (mean age 46 years). In this study, the median urinary F concentration was $2 \mathrm{mg} / \mathrm{L}$ with approximately 59\% of urine samples having a F concentration $\geq 1.6 \mathrm{mg} / \mathrm{L}$. [238]. Similarly, Kumar and Harper previously reported that evidence of renal damage, increased urinary ALB and vascular calcification were associated with skeletal fluorosis [239].

Human studies have also shown that circulating ALB levels of individuals with skeletal fluorosis as well as the concentration of salivary albumin in children with dental fluorosis are significantly lower than in healthy controls without fluorosis [240-242]. Studies have also shown that high blood glucose levels significantly reduce serum ALB levels [243], which is consistent with the previous observations that megalin expression is inhibited by glucose $[219,220]$. Also, as previously noted, the salivary glands play a role in recycling iodine for uptake in the gastrointestinal tract [69]. Thus, lower salivary ALB increased urinary excretion of ALB and lower blood levels of ALB in systemic circulation can contribute to depletion of iodine stores in the body and iodine deficiency. Taken together, this data may explain the findings of Singla and Shashi who observed increased urinary loss of iodine in patients with thyroid dysfunction residing in an endemic fluorosis area [13]. From a pharmacokinetic point of view, it has further been demonstrated that megalin excretion is enhanced in the urine of patients with moderate increase in the level of urine ALB [244]. This suggests that the binding of megalin to ALB and increased excretion of ALB which occurs during F intoxication, may further contribute to elimination of megalin with implications for homeostatic regulation of iodine. It is essential to also clarify that NIS is localized at the opposite apical (Ap) surface of the proximal and cortical collecting tubes in the kidney and participates in iodine reabsorption [245]. Accordingly, loss of NIS or inhibition of Na+, K+-ATPase which is required for NIS functionality, can result in impaired reabsorption of iodine, which can in turn contribute to iodine depletion. Interestingly, in hypothyroidism the activity of $\mathrm{Na}(+)-\mathrm{K}(+)$-ATPase is reduced initially in the proximal tubules and later in almost all segments of the nephron [246]. As previously described, iodine deficiency leads to increased TSH secretion which can result in hypothyroidism. It is important to mention that while, results from several animal and in vitro studies suggest that TSH directly stimulates NIS mRNA expression and protein levels in the thyroid gland [247-250], evidence from human studies have demonstrated that serum TSH levels have not been found to be associated with NIS expression $[100,251,252]$. 


\section{Discussion}

In this work, the key mechanisms by which $\mathrm{F}$ inhibits iodine absorption thereby contributing to iodine deficiency within the population have been presented. Evidence demonstrates that $\mathrm{F}$ impairs iodine absorption and transport by two key mechanisms; inhibition of NIS gene expression and inhibition of $\mathrm{Na}+, \mathrm{K}+$-ATPase activity. NIS mediates iodine uptake in the gastrointestinal tract as well as uptake of iodine into the thyroid, salivary, gastric mucosa and mammary glands. In relation to NIS functionality in iodine absorption and transport the crucial role of $\mathrm{Na}+, \mathrm{K}+-\mathrm{ATPase}$ activity has been elucidated. It is also known that $\mathrm{F}$ inhibits $\mathrm{Na}+, \mathrm{K}+$-ATPase activity and the molecular mechanism by which this occurs have recently been described [96].

In this study, evidence has been presented demonstrating NIS gene expression is activated by PRL and that F inhibits PRL expression. Importantly, it has also been elucidated that the inhibitory effect is significantly more prevalent in females than males. It has further been shown that CT is a PRL-inhibiting hormone and that $\mathrm{F}$ is a potent inducer of $\mathrm{CT}$ expression. Furthermore, evidence has been presented that TNF- $\alpha$, TGF- $\beta 1$, IL- 6 and IL- $1 \beta$, IFN- $\gamma$, IGF-1, PI3K and Tg inhibit NIS expression and that F upregulates TNF- $\alpha$, TGF- $\beta 1$, IL-6 and IL-1 $\beta$, IFN- $\gamma$, IGF-1, PI3K and Tg expression and activity.

In addition to providing causal mechanisms by which $\mathrm{F}$ impairs iodine metabolism an important consideration in demonstrating a causal association between $\mathrm{F}$ intake and impaired iodine deficiency is evidence from epidemiological studies. In this regard, I have previously elucidated that evidence from several epidemiological studies undertaken in different geographic locations among different ethnic populations consistency shown an association between $\mathrm{F}$ exposure and impaired iodine bioavailability. Furthermore, evidence for animal studies support this observation. In addition, I have previously elucidated how the mean UICs have declined dramatically in recent decades in countries with advanced water fluoridation programmes.

It is important to note that the most obvious and the earliest clinical manifestation of $\mathrm{F}$ toxicity is dental fluorosis, which can develop in children, due to the intake of high levels of F during the period of tooth development, and clinically, it is the marker of F toxicity in the first six years of life [253]. The increasing population exposure to $\mathrm{F}$ is clearly evident in the rising burden of dental fluorosis as reported in the US and other countries with water fluoridation in recent decades. Revealing the dramatic decline in UICs observed in these countries in recent decades parallels the dramatic increase in the prevalence of dental fluorosis. For example, in the US, the prevalence of dental fluorosis was $9 \%$ among children born in the period 1961-1970, compared to $22.6 \%$ among children born between 1984-1985 and 41\% among all US children born between 1984-1985 [254]. In 2004, Marshall et al. reported that the prevalence of fluorosis in permanent teeth in areas with fluoridated water in the USA increased from about $10-15 \%$ in the 1940 s to as high as $70 \%$ in recent studies [255]. Similarly, among children aged 15 years the prevalence of dental fluorosis increased seven-fold in fluoridated communities in the RoI between 1984 and 2002 [256]. In this regard, it is important to identify that a comprehensive review of the available literature on disorders induced by iodine deficiency previously reported that iodine deficiency among the paediatric population may result in significantly lower iodine stores in the thyroid and significantly reduce the thyroid exchangeable hormonal iodine pool in adulthood [257].

In this study, I have also discussed the crucial role of megalin in regulating iodine stores and presented evidence to show that $\mathrm{F}$ inhibits megalin expression as well as elucidated the molecular mechanisms by which this occurs. I have further elucidated how iodine is also carried in the blood stream bound to ALB and that high serum ALB correlates with high protein bound iodine levels. I have described how the literature shows that F exposure results in loss of ALB in urine contributing to lower salivary and serum ALB levels. Additionally, I have discussed how chronic F exposure has been found to result in lowering of protein bound iodine levels, indicating that $\mathrm{F}$ intoxication is contributing to iodine deficiency by lowering iodine stores. I have also elucidated that evidence from animal studies show that increased $\mathrm{F}$ intake combined with iodine deficiency significantly enhances 
the toxic effects of $\mathrm{F}$ on teeth, bones, thyroid and brain. Taken together, these data may explain the dramatic increase in dental fluorosis observed in fluoridated communities in recent decades. Moreover, the evidence presented in this study offers a rational for the remarkably decline in UIC among females of reproductive age observed in countries with extensive water fluoridation programmes in recent decades. As mentioned previously, iodine deficiency in infancy can also lead to impaired iodine stores in adulthood.

As previously described, it is well recognized that impaired cognitive development in offspring is associated with maternal iodine deficiency [4]. In addition, a growing body of evidence exists that shows an association between iodine deficiency/hypothyroidism, attention deficit hyperactivity disorder (ADHD) [258-262] and autism spectrum disorders (ASD) [263-268]. As elucidated in this study, given the diverse role of $\mathrm{F}$ in inhibiting NIS expression and functionality, including the crucial role of $\mathrm{F}$ in inhibiting $\mathrm{Na}+\mathrm{K}+-\mathrm{ATPase}$ activity, as recently reported [96], it is expected that maternal $\mathrm{F}$ exposure will increase the risk of neurodevelopmental disorders in offspring. Taken together, this suggests that $\mathrm{F}$ intake should be minimized in infancy, and especially among females prior to and during pregnancy to ensure adequate iodine stores are available for the developing foetus.

According to the $\mathrm{WHO}$, in iodine-deficient communities, between 10 and 15 intelligence quotients (IQ) points may be lost when compared to similar but non-iodine-deficient populations [269]. Revealing, Lynn and Vanhanen examined differences in the average IQ of children for over 80 nations internationally for which data on the average national IQ were available. According to the authors, the median national IQ for the RoI was significantly below that of other European nations including the UK, The Netherlands, Austria, Germany, Sweden, Estonia, Belgium, France, Switzerland, Czech Rep, Denmark, Italy, Finland, Spain, Slovenia, Hungary and Ukraine [270]. Interestingly, the authors reported that between 1988 and 1993 the mean IQ among children aged 6-12 years in the RoI declined by 4 IQ points from 97 to 93 [270]. Furthermore, in 2012, the mean IQ of children aged 6 years in the RoI was reported to be 92. It is important to note that the drop in IQ follows the trend of the reduction in UIC among females of reproductive age [23] and the increasing prevalence of dental fluorosis among children born in RoI in recent decades [256] Furthermore, the RoI is the only country in Europe with mandatory artificial fluoridation of drinking water. As previously elucidated, the combination of low iodine status and high $\mathrm{F}$ intake has been found in animal studies to result in enhanced toxic effects of fluorosis on teeth [43] and brains [41]. The trend of declining IQ in children with increasing prevalence of dental fluorosis observed in the RoI is consistent with the findings of several cross-sectional studies conducted in China and India which documented an association between loss of IQ and dental fluorosis in children [271-277]. Taken together, these results suggest that water fluoridation and F intake has contributed to a significant loss of IQ in children in the RoI. This observation is consistent with the recent findings from two well designed longitudinal studies which found that prenatal exposure to $\mathrm{F}$ was associated with cognitive impairment and increased risk of ADHD in offspring [278,279].

\section{Additional Perspectives}

In addition to the biological actions of iodine in regulating thyroid hormones, iodine has many additional functions, including anti-inflammatory [280-283], antioxidant [284-287] and anti-microbial defence [288-294]. Iodine deficiency has been reported to be associated with increased cancer risk [295] including; breast [286,296-299], thyroid [300-306], and prostate cancer [307,308]. Furthermore, iodine has been found to inhibit the carcinogenic process in breast and prostate cancer cell lines [309-312]. These findings are consistent with results showing that incidence of prostate, endometrium, ovary and breast cancer is lower in populations with high iodine intake [245,299]. Notably, the RoI has the highest cancer incident in Europe and third highest in the world next to New Zealand and Australia [313,314]. The majority of the population in all three countries are also provided with artificially fluoridated drinking water.

The current study has elucidated the role of $\mathrm{F}$ in inhibiting PRL expression. It is important to note, that in addition the role of PRL in upregulating NIS expression, PRL is known to have more than 
300 biological functions including the stimulation of neurogenesis, modulation of stress responses, calcium transport, immune system regulation and reduction of anxiety, among others [315-319]. Recently, it has been found that PRL increases synaptogenesis and neuronal plasticity, enhances neurogenesis, cell proliferation and neuroprotection, improves learning and spatial memory and acts as a neuronal protector against excitotoxicity-effects [320-330]. Thus, it seems reasonable to suggest that suppression of PRL may be deleterious to brain activity. However, PRL is also essential for promoting milk production after birth [331]. Thus, inhibition of PRL can lead to problems with breastfeeding. Low PRL is associated with increased risk of type 2 diabetes (TSDM), particularly for females [332,333]. Globally, the number of people with diabetes mellitus has quadrupled in the past three decades, and diabetes mellitus is the ninth major cause of death. About 1 in 11 adults worldwide now have diabetes mellitus, $90 \%$ of whom have T2DM [334]. In males, low PRL has been found to be related to sexual dysfunction, metabolic syndrome, anxiety and depressive symptoms and lower general health. $[335,336]$. In line with this finding, in a longitudinal evaluation of the same subjects, it was recently reported that low PRL independently predicted incident major cardiovascular events [337].

\section{Conclusions}

In summary, diverse lines of evidence demonstrate that F inhibits NIS expression and functionality thereby contributing to impaired iodide absorption, diminished iodide-concentrating ability and iodine deficiency disorders. Taken together, the findings of this study provide unprecedented insights into the molecular mechanisms by which $\mathrm{F}$ inhibits iodine uptake, transport and reabsorption, and provide a basis for minimising or preventing the risk of adverse health outcomes associated with iodine deficiency. The findings of this study further suggest that there are windows of susceptibility over the life course where chronic F exposure in infancy may influence long term iodine status and health outcomes in adulthood. Moreover, iodine deficiency in pregnancy can have profound implications on the health of offspring including risk of miscarriage, stillbirth, reduced IQ and greater risk of ADHD and ASD. In addition, loss of iodine bioavailability leads to lower antioxidant capacity, reduced anti-inflammatory capacity, impaired immunity and increased risk of cancer. Therefore, actions that prevent the risk of adverse health outcomes are essential to improve the health of the world's population and to reduce health inequities. Based on the findings of this study, evidence strongly suggests that $\mathrm{F}$ ingestion contributes to pathological states by impairing iodine absorption and diminishing iodine concentrating ability. Whether or not public health practitioners and epidemiologists are ready to take up the implied challenge of these findings is, inevitably, related to the extent to which they are willing to continue to disavow the emerging evidence that $\mathrm{F}$ intake is associated with negative health outcomes for the sake of continuing a policy of fluoridation of drinking water that inadvertently may be contributing to the pathogenesis of neurodevelopmental disorders, impaired immune responses, inflammatory diseases and cancer.

Author Contributions: D.T.W. is solely responsible for the intellectual content, literature review and drafting of the manuscript. The author reviewed and approved the final manuscript.

Funding: The author did not receive payment or benefit for this work. This work was undertaken without funding for the benefit of public health and the advancement of scientific education in the fields of health promotion and disease prevention.

Conflicts of Interest: The author declares no conflict of interest.

\section{References}

1. Zimmermann, M.B.; Jooste, P.L.; Pandav, C.S. Iodine-deficiency disorders. Lancet 2008, 372, 1251-1262. [CrossRef]

2. Underwood, E.J. Trace Elements in Human and Animal Nutrition, 4th ed.; Academic Press: New York, NY, USA, 1977; p. 545, ISBN 0-12-709065-7. 
3. Hetzel, B.S. SOS for a Billion-The Nature and Magnitude of Iodine Deficiency Disorders, 2nd ed.; Hetzel, B.S., Pandav, C.V., Eds.; Oxford University Press: New Delhi, India, 1997; pp. 1-29.

4. De Benoist, B.; McLean, E.; Andersson, M.; Rogers, L. Iodine Deficiency in 2007: Global Progress since 2003. Food Nutr. Bull. 2008, 29, 195-202. [CrossRef]

5. WHO/UNICEF/International Council for the Control of Iodine Deficiency Disorders. Assessment of Iodine Deficiency Disorders and Monitoring Their Elimination: A Guide for Programme Managers, 3rd ed.; World Health Organization: Geneva, Switzerland, 2007; Available online: http:/ /apps.who.int/iris/bitstream/handle/ 10665/43781/9789241595827_eng.pdf (accessed on 19 January 2019).

6. Iodine Status Worldwide. WHO Global Database on Iodine Deficiency; World Health Organization: Geneva, Switzerland, 2004; Available online: https://apps.who.int/iris/handle/10665/43010 (accessed on 19 January 2019).

7. Iodine Global Network. Global Iodine Nutrition Scorecard 2015; Iodine Global Network: Zurich, Switzerland, 2015; Available online: http://ign.org/cm_data/Scorecard_2015_August_26_new.pdf (accessed on 19 January 2019).

8. Pearce, E.N.; Lazarus, J.H.; Moreno-Reyes, R.; Zimmermann, M.B. Consequences of iodine deficiency and excess in pregnant women: An overview of current knowns and unknowns. Am. J. Clin. Nutr. 2016, 104 (Suppl. 3), 918S-923S. [CrossRef] [PubMed]

9. National Research Council. Review of Fluoride in Drinking Water, U.S.; The National Academic Press: Washington, DC, USA, 2006.

10. Li, Y.; Zhang, J.; Li, Z. Prevention of iodine deficiency in high fluoride areas in Tianjin City, China. Fluoride 1998, 31, S18.

11. Scientific Committee on Food. Opinion of the Scientific Committee on Food on the Tolerable Upper Intake Level of Iodine. SCF/CS/NUT/UPPLEV/26 Final 2002 October 7. Available online: https:/ / ec.europa.eu/ food/sites/food/files/safety/docs/sci-com_scf_out146_en.pdf (accessed on 19 January 2019).

12. Susheela, A.K.; Bhatnagar, M.; Vig, K.; Mondal, N.K. Excess fluoride ingestion and thyroid hormone derangements in children living in Delhi, India. Fluoride 2005, 38, 151-161.

13. Singla, S.; Shashi, A. Thyroid peroxidase activity as toxicity target for fluoride in patients with thyroid dysfunction. Curr. Res. Microbiol. Biotechnol. 2013, 1, 53-57.

14. Malin, A.J.; Riddell, J.; McCague, H.; Till, C. Fluoride exposure and thyroid function among adults living in Canada: Effect modification by iodine status. Environ. Int. 2018, 121, 667-674. [CrossRef] [PubMed]

15. Singh, N.; Verma, K.G.; Verma, P.; Sidhu, G.K.; Sachdeva, S. A comparative study of fluoride ingestion levels, serum thyroid hormone \& TSH level derangements, dental fluorosis status among school children from endemic and non-endemic fluorosis areas. SpringerPlus 2014, 3, 7. [PubMed]

16. Yang, Y.; Wang, X.; Guo, X. Effects of high iodine and high fluorine on children's intelligence and the metabolism of iodine and fluorine. Chin. J. Epidemiol. 1994, 15, 296-298.

17. Xue, G.; Li-Ju, D.; Yue, B.A. Influence of high fluoride concentration in drinking water on the function of children's Thyroid. Henan J. Prev. Med. 2009, 03. Available online: http:/ / en.cnki.com.cn/Article_en/ CJFDTOTAL-HNYF200903004.htm (accessed on 19 January 2019).

18. Mikhailets, N.D.; Balabolkin, M.I.; Rakitin, V.A.; Danilov, I.P. Thyroid function during prolonged exposure to fluorides. Probl. Endocrinol. 1996, 42, 6-9.

19. Iodine Status on the Island of Ireland; Safefood Ireland: Cork, Ireland, 2018; p. 7. Available online: https:/ / www.safefood.eu/SafeFood/media/SafeFoodLibrary/Documents/Publications/Research\% 20Reports/Iodine-Status-on-the-island-of-Ireland-23032018.pdf (accessed on 19 January 2019).

20. O'Sullivan, V.; O'Connell, B.C. Water fluoridation, dentition status and bone health of older people in Ireland. Community Dent. Oral Epidemiol. 2015, 43, 58-67. [CrossRef] [PubMed]

21. Zimmermann, M.B.; Aeberli, I.; Melse-Boonstra, A.; Grimci, L.; Bridson, J.; Chaouki, N.; Mbhenyane, X.; Jooste, P.L. Iodine treatment in children with subclinical hypothyroidism due to chronic iodine deficiency decreases thyrotropin and C-peptide concentrations and improves the lipid profile. Thyroid 2009, 19, 1099-1104. [CrossRef] [PubMed]

22. Hollowell, J.G.; Staehling, N.W.; Hannon, W.H.; Flanders, D.W.; Gunter, E.W.; Maberly, G.F.; Braverman, L.E.; Pino, S.; Miller, D.T.; Garbe, P.L.; et al. Iodine nutrition in the United States. Trends and public health implications: Iodine excretion data from National Health and Nutrition Examination Surveys I and III (1971-1974 and 1988-1994). J. Clin. Endocrinol. Metab. 1998, 83, 3401-3408. 
23. Li, M.; Ma, G.; Boyages, S.; Eastman, C. Re-emergence of iodine deficiency in Australia. Asia Pac. J. Clin. Nutr. 2001, 10, 200-203. [CrossRef]

24. Thomson, C.D.; Packer, M.A.; Butler, J.A.; Duffield, A.J.; O’Donaghue, K.L.; Whanger, P.D. Urinary selenium and iodine during pregnancy and lactation. J. Trace Elem. Med. Biol. 2001, 14, 210-217. [CrossRef]

25. Cooper, G.J.S.; Croxson, M.S.; Ibbertson, H.K. Iodine intake in an urban environment: A study of urine iodide excretion in Auckland. N. Z. Med. J. 1984, 97, 142-145.

26. Simpson, E.O.; Thaler, B.I.; Paulin, J.M.; Phelan, E.L.; Cooper, G.J.S. Iodide excretion in a salt-restriction trial. N. Z. Med. J. 1984, 97, 890-893.

27. Smyth, P.; Burns, R.; Casey, M.; Mullan, K.; O'Herlihy, C.; O'Dowd, C. Iodine Status over Two Decades: Influence of Seaweed Exposure. Ir. Med. J. 2016, 109, 421. [PubMed]

28. Peckham, S.; Lowery, D.; Spencer, S. Are fluoride levels in drinking water associated with hypothyroidism prevalence in England? A large observational study of GP practice data and fluoride levels in drinking water. J. Epidemiol. Community Health 2015, 69, 619-624. [CrossRef]

29. Kheradpisheh, Z.; Mirzaei, M.; Mahvi, A.H.; Mokhtari, M.; Azizi, R.; Fallahzadeh, H.; Ehrampoush, M.H. Impact of Drinking Water Fluoride on Human Thyroid Hormones: A Case-Control Study. Sci. Rep. 2018, 8, 2674. [CrossRef]

30. Trabelsi, M.; Guermazi, F.; Zeghal, N. Effect of fluoride on thyroid function and cerebellar development in mice. Fluoride 2001, 34, 165-173.

31. Bouaziz, H.; Soussia, L.; Guermazi, F.; Zeghal, N. Fluoride-induced thyroid proliferative changes and their reversal in female mice and their pups. Fluoride 2005, 38, 185-192.

32. Bouaziz, H.; Ammar, E.; Ghorbel, H.; Ketata, S.; Jamoussi, K.; Ayadi, F.; Guermazi, F.; Zeghal, N. Effect of fluoride ingested by lactating mice on the thyroid function and bone maturation of their suckling pups. Fluoride 2004, 37, 133-142.

33. Ahmed, O.M.; Abd El-Tawab, S.M.; Ahmed, R.G. Effects of experimentally induced maternal hypothyroidism and hyperthyroidism on the development of rat offspring: I. The development of the thyroid hormones-neurotransmitters and adenosinergic system interactions. Int. J. Dev. Neurosci. 2010, 28, 437-454. [CrossRef]

34. Ren, D.; Li, K.; Liu, D. A study of the intellectual ability of 8-14 year-old children in high fluoride, low iodine areas. Chin. J. Control Endem. Dis. 1989, 4, 251.

35. Lin, F.F.; Aihati, H.T.; Zhao, H.X.; Jin, L.; Jiang, J.-Y.; Maimaiti, A. The relationship of a low-iodine and high-fluoride environment to subclinical cretinism in Xinjiang. Endem. Dis. Bull. 1991, 6, 62-67.

36. Hong, F.; Cao, Y.; Wang, H. A study of fluorine effects on children's intelligence development under different environments. Chin. Prim. Health Care 2001, 15, 56-57.

37. Ge, Y.; Ning, H.; Wang, S.; Wang, J. Effects of high fluoride and low iodine on brain histopathology in offspring rats. Fluoride 2005, 38, 127-132.

38. Wang, J.D.; Ge, Y.M.; Ning, H.M.; Wang, S.L. Effects of high fluoride and low iodine on biochemical indexes of the brain and learning-memory of offspring rats. Fluoride 2004, 37, 201-208.

39. Zhao, W.; Zhu, H.; Yu, Z.; Aoki, K.; Misumi, J.; Zhang, X. Long term effects of various iodine and fluorine doses on the thyroid and fluorosis in mice. Endocr. Regul. 1998, 32, 63-70.

40. Ge, Y.; Ning, H.; Wang, S.; Wang, J. DNA Damage in Thyroid Gland Cells of Rats Exposed to Long-Term Intake of High Fluoride and Low Iodine. Fluoride 2005, 38, 318-323.

41. Cinar, A.; Selsuk, M. Effects of chronic fluorosis on thyroxine, triiodothyronine, and protein-bound iodine in cows. Fluoride 2005, 38, 65-68.

42. Bildik, A.; Camas, H. The research of some specific liver enzyme activities and PBI values in the blood serums of sheep with fluorosis. Kafkas Univ. Fen Bil. Derg. 1996, 1, 16-23.

43. Guan, Z.Z.; Zhuang, Z.J.; Yang, P.S.; Pan, S. Synergistic action of iodine-deficiency and fluorine intoxication on rat thyroid. Chin. Med. J. 1988, 101, 679-684. [PubMed]

44. Kundel, M.; Thorenz, U.R.; Petersen, J.H.; Huang, R.J.; Bings, N.H.; Hoffmann, T. Application of mass spectrometric techniques for the trace analysis of short-lived iodine-containing volatiles emitted by seaweed. Anal. Bioanal. Chem. 2012, 402, 3345-3357. [CrossRef]

45. Gilfedder, B.S.; Petre, M.; Biester, H. Iodine speciation in rain and snow: Implications for the atmospheric iodine sink. J. Geophys. Res. 2007, 112, D07301. [CrossRef] 
46. Baker, A.R. Marine Aerosol Iodine Chemistry: The Importance of Soluble Organic Iodine. Environ. Chem. 2005, 2, 295-298. [CrossRef]

47. McFiggans, G.; Coe, H.; Burgess, R.; Allan, J.; Cubison, M.; Alfarra, M.R.; Saunders, R.; Saiz-Lopez, A.; Plane, J.M.C.; Wevill, D.J.; et al. Direct evidence for coastal iodine particles from Laminaria macroalgae-linkage to emissions of molecular iodine. Atmos. Chem. Phys. 2004, 4, 701-713. [CrossRef]

48. Carperter, L.J. Iodine in the marine boundary layer. Chem. Rev. 2003, 103, 4953-4962. [CrossRef]

49. O'Dowd, C.D.; Jimenez, J.L.; Bahreini, R.; Flagan, R.C.; Seinfeld, J.H.; Hämeri, K.; Pirjola, L.; Kulmala, M.; Jennings, S.G.; Hoffmann, T. Marine aerosol formation from biogenic iodine emissions. Nature 2002, 417, 632-636. [CrossRef] [PubMed]

50. McFiggans, G.; Plane, J.M.C.; Allan, B.J.; Carpenter, L.J.; Coe, H.; O’Dowd, C. A modeling study of iodine chemistry in the marine boundary layer. J. Geophys. Res. 2000, 105, 14371-14385. [CrossRef]

51. Duce, R.A.; Winchester, J.W.; Van Nahl, T.W. Iodine, bromine, and chlorine in winter aerosols and snow from Barrow, Alaska. Tellus 1966, 18, 238-248. [CrossRef]

52. Rohner, F.; Zimmermann, M.; Jooste, P.; Pandav, C.; Caldwell, K.; Raghavan, R.; Raiten, D.J. Biomarkers of Nutrition for Development-Iodine Review. J. Nutr. 2014, 144, 1322S-1342S. [CrossRef] [PubMed]

53. Smyth, P.P.; Burns, R.; Huang, R.J.; Hoffman, T.; Mullan, K.; Graham, U.; Seitz, K.; Platt, U.; O'Dowd, C. Does iodine gas released from seaweed contribute to dietary iodine intake? Environ. Geochem. Health 2011, 33, 389-397. [CrossRef]

54. Vought, R.L.; London, W.T.; Brown, F.A. A note on atmospheric iodine and its absorption in man. J. Clin. Endocrinol. Metab. 1964, 24, 414-416. [CrossRef] [PubMed]

55. Nagataki, S. The average of dietary iodine intake due to the ingestion of seaweeds is $1.2 \mathrm{mg} /$ day in Japan. Thyroid 2008, 18, 667-668. [CrossRef]

56. O'Brien, B.; Gleeson, D.; Jordan, K. Iodine concentrations in milk. Ir. J. Agric. Food Res. 2013, 52, $209-216$.

57. Borucki Castro, S.I.; Berthiaume, R.; Laffey, P.; Fouquet, A.; Beraldin, F.; Robichaud, A.; Lacasse, P. Iodine concentration in milk sampled from Canadian farms. J. Food Prot. 2010, 73, 1658-1663. [CrossRef] [PubMed]

58. Rose, M.; Miller, P.; Baxter, M.; Appleton, G.; Crews, H.; Croasdale, M. Bromine and iodine in 1997 UK total diet study samples. J. Environ. Monit. 2001, 3, 361-365. [CrossRef]

59. Pennington, J.A.T. Iodine Concentrations in US Milk: Variation Due to Time, Season, and Region. J. Dairy Sci. 1990, 73, 3421-3427. [CrossRef]

60. Galton, D.M.; Petersson, L.G.; Erb, H.N. Milk iodine residues in herds practicing iodophor premilking teat disinfection. J. Dairy Sci. 1986, 69, 267-271. [CrossRef]

61. Haldimann, M.; Alt, A.; Blanc, A.; Blondeau, K. Iodine content of food groups. J. Food Compos. Anal. 2005, 18, 461-471. [CrossRef]

62. Pennington, J.A.T.; Schoen, S.A.; Salmon, G.D.; Young, B.; Johnson, R.D.; Marts, R.W. Composition of core foods in the U.S. food supply. J. Food Compos. Anal. 1995, 8, 171-217. [CrossRef]

63. Lu, Y.L.; Wang, N.J.; Zhu, L.; Wang, G.X.; Wu, H.; Kuang, L.; Zhu, W.M. Investigation of iodine concentration in salt, water and soil along the coast of Zhejiang, China. J. Zhejiang Univ. Sci. B 2005, 6, 1200-1205. [CrossRef] [PubMed]

64. Pedersen, K.M.; Laurberg, P.; Nohr, S.; Jorgensen, A.; Andersen, S. Iodine in drinking water varies by more than 100-fold in Denmark. Importance for iodine content of infant formulas. Eur. J. Endocrinol. 1999, 140, 400-403. [CrossRef] [PubMed]

65. Whitehead, D.C. Iodine in the U.K. Environment with Particular Reference to Agriculture. J. Appl. Ecol. 1979, 16, 269-279. [CrossRef]

66. Leung, A.M.; Braverman, L.E.; Pearce, E.N. History of U.S. iodine fortification and supplementation. Nutrients 2012, 4, 1740-1746. [CrossRef] [PubMed]

67. Pesce, L.; Kopp, P. Iodide transport: Implications for health and disease. Int. J. Pediatr. Endocrinol. 2014, 2014, 8. [CrossRef]

68. Nicola, J.P.; Basquin, C.; Portulano, C.; Reyna-Neyra, A.; Paroder, M.; Carrasco, N. The Na ${ }^{+} / \mathrm{I}^{-}$symporter mediates active iodide uptake in the intestine. Am. J. Physiol. Cell Physiol. 2009, 296, C654-C662. [CrossRef] [PubMed]

69. Brown-Grant, K. Extrathyroidal iodide concentrating mechanisms. Physiol. Rev. 1961, 41, 189-213. [CrossRef]

70. Ahad, F.; Ganie, S.A. Iodine, Iodine metabolism and Iodine deficiency disorders revisited. Indian J. Endocrinol. Metab. 2010, 14, 13-17. [PubMed] 
71. Caillou, B.; Troalen, F.; Baudin, E.; Talbot, M.; Filetti, S.; Schlumberger, M.; Bidart, J.M. Na ${ }^{+} / \mathrm{I}^{-}$symporter distribution in human thyroid tissues: An immunohistochemical study. J. Clin. Endocrinol. Metab. 1998, 83, 4102-4106. [CrossRef]

72. Eskandari, S.; Loo, D.D.F.; Dai, G.; Levy, O.; Wright, E.M.; Carrasco, N. Thyroid $\mathrm{Na}^{+} / \mathrm{I}^{-}$symporter mechanism, stoichiometry, and specificity. J. Biol. Chem. 1997, 272, 27230-27238. [CrossRef]

73. Jomaa, B. Thyroid Toxicogenomics: A Multi-Organ Paradigm. In Toxicogenomics-Based Cellular Models; Kleinjans, J., Ed.; Elsevier Academic Press: Cambridge, MA, USA, 2014; pp. 159-189.

74. Dohán, O.; De la Vieja, A.; Paroder, V.; Riedel, C.; Artani, M.; Reed, M.; Ginter, C.S.; Carrasco, N. The sodium/iodide Symporter (NIS): Characterization, regulation, and medical significance. Endocr. Rev. 2003, 24, 48-77. [CrossRef] [PubMed]

75. Hingorani, M.; Spitzweg, C.; Vassaux, G.; Newbold, K.; Melcher, A.; Pandha, H.; Vile, R.; Harrington, K. The Biology of the Sodium Iodide Symporter and its Potential for Targeted Gene Delivery. Curr. Cancer Drug Targets 2010, 10, 242-267. [CrossRef] [PubMed]

76. Dai, G.; Levy, O.; Carrasco, N. Cloning and characterization of the thyroid iodide transporter. Nature 1996, 379, 458-460. [CrossRef] [PubMed]

77. Spitzweg, C.; Joba, W.; Eisenmenger, W.; Heufelder, A.E. Analysis of human sodium iodide symporter gene expression in extrathyroidal tissues and cloning of its complimentary deoxyribonucleic acids from salivary gland, mammary gland and gastric mucosa. J. Clin. Endocrinol. Metab. 1998, 83, 1746-1751. [CrossRef] [PubMed]

78. Di Jeso, B.; Arvan, P. Thyroglobulin from Molecular and Cellular Biology to Clinical Endocrinology. Endocr. Rev. 2015, 37, 2-36. [CrossRef]

79. Lisi, S.; Pinchera, A.; McCluskey, R.T.; Willnow, T.E.; Refetoff, S.; Marcocci, C.; Vitti, P.; Menconi, F.; Grasso, L.; Luchetti, F.; et al. Preferential megalin-mediated transcytosis of low-hormonogenic thyroglobulin: A control mechanism for thyroid hormone release. Proc. Natl. Acad. Sci. USA 2003, 100, 14858-14863. [CrossRef]

80. Marinò, M.; Pinchera, A.; McCluskey, R.T. Megalin in thyroid physiology and pathology. Thyroid 2001, 11, 47-56. [CrossRef]

81. Marinò, M.; Zheng, G.; Chiovato, L.; Pinchera, A.; Brown, D.; Andrews, D.; McCluskey, R.T. Role of megalin (gp330) in transcytosis of thyroglobulin by thyroid cells. A novel function in the control of thyroid hormone release. J. Biol. Chem. 2000, 275, 7125-7137. [CrossRef] [PubMed]

82. Luo, Y.; Ishido, Y.; Hiroi, N.; Ishii, N.; Suzuki, K. The Emerging Roles of Thyroglobulin. Adv. Endocrinol. 2014, 2014, 189194. [CrossRef]

83. Abrams, G.M.; Larsen, P.R. Triiodothyronine and thyroxine in the serum and thyroid glands of iodine-deficient rats. J. Clin. Investig. 1973, 52, 2522-2531. [CrossRef] [PubMed]

84. De Vijlder, J.J. Primary congenital hypothyroidism: Defects in iodine pathways. Eur. J. Endocrinol. 2003, 149, 247-256. [CrossRef]

85. Zimmermann, M.B. Iodine and iodine deficiency disorders. In Present Knowledge in Nutrition, 10th ed.; Erdman, J.W., Macdonald, I.A., Zeisel, S.H., Eds.; Wiley-Blackwell: Oxford, UK, 2012; pp. 554-567.

86. Zimmermann, M.B. Methods to assess iron and iodine status. Br. J. Nutr. 2008, 99 (Suppl. 3), S2-S9. [CrossRef]

87. Alexander, W.D.; Harden, R.M.; Harrison, M.T.; Shimmins, J. Some aspects of the absorption and concentration of iodide by the alimentary tract in man. Proc. Nutr. Soc. 1967, 26, 62-66. [CrossRef] [PubMed]

88. DeGroot, L.J. Kinetic analysis of iodine metabolism. J. Clin. Endocrinol. Metab. 1966, 26, 149-173. [CrossRef] [PubMed]

89. Stanbury, J.B.; Brownell, G.L.; Riggs, D.S.; Perinetti, H.; Itoiz, J.; Del Castillo, E.B. Endemic goiter. In The Adaptation of Man to Iodine Deficiency; Stanbury, J.B., Ed.; Harvard University Press: Cambridge, MA, USA, 1954; pp. 1-209.

90. Wayne, E.J.; Koutras, D.A.; Alexander, W.D. Clinical Aspects of Iodine Metabolism; Blackwell Scientific: Oxford, UK, 1964.

91. Zimmermann, M.B. Iodine deficiency. Endocr. Rev. 2009, 30, 376-408. [CrossRef]

92. Glinoer, D. The regulation of thyroid function in pregnancy: Pathways of endocrine adaptation from physiology to pathology. Endocr. Rev. 1997, 18, 404-433. [CrossRef] 
93. Karam, G.A.; Hakimi, H.; Rezaeian, M.; Gafarzadeh, H.; Rashidinejad, H.; Khaksari, M. Thyroid function in mothers who gave birth to neonates with transient congenital hypothyroidism. Pak. J. Med. Sci. 2009, 25, 568-572.

94. Azizi, F.; Smyth, P. Breastfeeding and maternal and infant iodine nutrition. Clin. Endocrinol. 2009, 70, 803-809. [CrossRef] [PubMed]

95. Simon, S.L.; Luckyanov, N.; Bouville, A.; VanMiddlesworth, L.; Weinstock, R.M. Transfer of 131I into human breast milk and transfer coefficients for radiological dose assessments. Health Phys. 2002, 82, 796-806. [CrossRef]

96. Waugh, D.T. Molecular Mechanisms of Fluoride inhibition of $\mathrm{Na}^{+}, \mathrm{K}^{+}$-ATPase activity: Implications for Public Health and Health Inequalities. Int. J. Environ. Res. Public Health 2019, in press.

97. Pekary, A.E.; Levin, S.R.; Johnson, D.G.; Berg, L.; Hershman, J.M. Tumor necrosis factor-alfa (TNF-alfa) and transforming growth factor beta1 (TGF-beta1) inhibit the expression and activity of $\mathrm{Na}^{+} / \mathrm{K}^{+}$ATPase in FRTL-5 rat thyroid cells. J. Interferon Cytokine Res. 1997, 4, 185-195. [CrossRef]

98. Ajjan, R.A.; Watson, P.F.; Findlay, C.; Metcalfe, R.A.; Crisp, M.; Ludgate, M.; Weetman, A.P. The sodium iodide symporter gene and its regulation by cytokines found in autoimmunity. J. Endocrinol. 1998, 158, 351-358. [CrossRef]

99. Pekary, A.E.; Hershman, J.M. Tumor necrosis factor, ceramide, transforming growth factor-beta1, and aging reduce $\mathrm{Na}^{+} / \mathrm{I}^{-}$sym-porter messenger ribonucleic acid levels in FRTL-5 cells. Endocrinology 1998, 139, 703-712. [CrossRef] [PubMed]

100. Popławska-Kita, A.; Telejko, B.; Siewko, K.; Kościuszko-Zdrodowska, M.; Wawrusewicz-Kurylonek, N.; Krętowski, A.; Hryniewicka, J.; Dzięcioł, J.; Bauer, W.; Milewski, R.; et al. Decreased Expression of Thyroglobulin and Sodium Iodide Symporter Genes in Hashimoto's Thyroiditis. Int. J. Endocrinol. 2014, 2014, 690704. [CrossRef]

101. Pang, X.P.; Park, M.; Hershman, J.M. Transforming growth factor-beta blocks protein kinase-A-mediated iodide transport and protein kinase-C-mediated DNA synthesis in FRTL-5 rat thyroid cells. Endocrinology 1992, 131, 45-50. [CrossRef] [PubMed]

102. Kawaguchi, A.; Ikeda, M.; Endo, T.; Kogai, T.; Miyazaki, A.; Onaya, T. Transforming growth factor-beta1 suppresses thyrotropin-induced $\mathrm{Na}^{+} / \mathrm{I}^{-}$symporter messenger RNA and protein levels in FRTL-5 rat thyroid cells. Thyroid 1997, 7, 789-794. [CrossRef]

103. Spitzweg, C.; Joba, W.; Morris, J.C.; Heufelder, A.E. Regulation of sodium iodide symporter gene expression in FRTL-5 rat thyroid cells. Thyroid 1999, 9, 821-830. [CrossRef]

104. Caturegli, P.; Hejazi, M.; Suzuki, K.; Dohan, O.; Carrasco, N.; Kohn, L.D.; Rose, N.R. Hypothyroidism in transgenic mice expressing IFN-y in the thyroid. Proc. Natl. Acad. Sci. USA 2000, 97, 1719-1724. [CrossRef]

105. Cass, L.A.; Meinkoth, J.L. Ras signaling through PI3K confers hormone-independent proliferation that is compatible with differentiation. Oncogene 2000, 19, 924-932. [CrossRef] [PubMed]

106. García, B.; Santisteban, P. PI3K is involved in the IGF-I inhibition of TSH-induced sodium/iodide symporter gene expression. Mol. Endocrinol. 2002, 16, 342-352. [CrossRef] [PubMed]

107. Royaux, I.E.; Suzuki, K.; Mori, A.; Katoh, R.; Everett, L.A.; Kohn, L.D.; Green, E.D. Pendrin, the protein encoded by the Pendred syndrome gene (PDS)is an apical porter of iodide in the thyroid and is regulated by thyroglobulin. Endocrinology 2000, 141, 839-845. [CrossRef]

108. Suzuki, K.; Lavaroni, S.; Mori, A.; Ohta, M.; Saito, J.; Pietrarelli, M.; Singer, D.S.; Kimura, S.; Katoh, R.; Kawaoi, A.; et al. Autoregulation of thyroid-specific gene transcription by thyroglobulin. Proc. Natl. Acad. Sci. USA 1998, 95, 8251-8256. [CrossRef] [PubMed]

109. Suzuki, K.; Mori, A.; Saito, J.; Moriyama, E.; Ullianich, L.; Kohn, L.D. Follicular thyroglobulin suppresses iodide uptake by suppressing expression of the sodium iodide symporter gene. Endocrinology 1999, 140, 5422-5430. [CrossRef]

110. Suzuki, K.; Mori, A.; Lavaroni, S.; Ulianich, L.; Miyagi, E.; Saito, J.; Nakazato, M.; Pietrarelli, M.; Shafran, N.; Grassadonia, A.; et al. Thyroglobulin regulates follicular function and heterogeneity by suppressing thyroid-specific gene expression. Biochimie 1999, 81, 329-340. [CrossRef]

111. Suzuki, K.; Mori, A.; Lavaroni, S.; Katoh, R.; Kohn, L.D.; Kawaoi, A. Thyroglobulin: A master regulator of follicular function via transcriptional suppression of thyroid specific genes. Acta Histochem. 1999, 32, 111-119. [CrossRef] 
112. Ulianich, L.; Suzuki, K.; Mori, A.; Nakazato, M.; Pietrarelli, M.; Goldsmith, P.; Pacifico, F.; Consiglio, E.; Formisano, S.; Kohn, L.D. Follicular thyroglobulin (TG) suppression of thyroid-restricted genes involves the apical membrane asialoglycoprotein receptor and TG phosphorylation. J. Biol. Chem. 1999, 274, 25099-25107. [CrossRef]

113. Kohn, L.D.; Suzuki, K.; Nakazato, M.; Royaux, I.; Green, E.D. Effects of thyroglobulin and pendrin on iodide flux through the thyrocyte. Trends Endocrinol. Metab. 2001, 12, 10-16. [CrossRef]

114. Ohmori, M.; Endo, T.; Harii, N.; Onaya, T. A novel thyroid transcription factor is essential for thyrotropin-induced up-regulation of $\mathrm{Na}^{+} / \mathrm{I}^{-}$symporter gene expression. Mol. Endocrinol. 1998, 12, 727-736.

115. Endo, T.; Kaneshige, M.; Nakazato, M.; Ohmori, M.; Harii, N.; Onaya, T. Thyroid transcription factor-1 activates the promoter activity of rat thytoid $\mathrm{Na}^{+} / \mathrm{I}^{-}$symporter gene. Mol. Endocrinol. 1997, 11, 1747-1755.

116. Joba, W.; Spitzweg, C.; Schriever, K.; Heufelder, A.E. Analysis of human sodium/iodide symporter, thyroid transcription factor-1, and paired-box-protein-8 gene expression in benign thyroid diseases. Thyroid 1999, 9, 455-466. [CrossRef] [PubMed]

117. Davies, T.F.; Ando, T.; Lin, R.Y.; Tomer, Y.; Latif, R. Thyrotropin receptor-associated diseases: From adenomata to Graves disease. J. Clin. Investig. 2005, 115, 1972-1983. [CrossRef] [PubMed]

118. Vaidya, B.; Campbell, V.; Tripp, J.H.; Spyer, G.; Hattersley, A.T.; Ellard, S. Premature birth and low birth weight associated with nonautoimmune hyperthyroidism due to an activating thyrotropin receptor gene mutation. Clin. Endocrinol. 2004, 60, 711-718. [CrossRef] [PubMed]

119. Rillema, J.A.; Yu, T.X.; Jhiang, S.M. Effect of prolactin on sodium iodide symporter expression in mouse mammary gland explants. Am. J. Physiol. Endocrinol. Metab. 2000, 279, E769-E772. [CrossRef] [PubMed]

120. Arturi, F.; Ferretti, E.; Presta, I.; Mattei, T.; Scipioni, A.; Scarpelli, D.; Bruno, R.; Lacroix, L.; Tosi, E.; Gulino, A.; et al. Regulation of iodide uptake and sodium/iodide symporter expression in the mcf-7 human breast cancer cell line. J. Clin. Endocrinol. Metab. 2005, 90, 2321-2326. [CrossRef] [PubMed]

121. Kogai, T.; Taki, K.; Brent, G.A. Enhancement of sodium/iodide symporter expression in thyroid and breast cancer. Endocr. Relat. Cancer 2006, 13, 797-826. [CrossRef] [PubMed]

122. Liu, Q.; Liu, H.; Yu, X.; Wang, Y.; Yang, C.; Xu, H. Analysis of the Role of Insulin Signaling in Bone Turnover Induced by Fluoride. Biol. Trace Elem. Res. 2016, 171, 380-390. [CrossRef]

123. Turner, C.H.; Garetto, L.P.; Dunipace, A.J.; Zhang, W.; Wilson, M.E.; Grynpas, M.D.; Chachra, D.; McClintock, R.; Peacock, M.; Stookey, G.K. Fluoride treatment increased serum IGF-1, bone turnover, and bone mass, but not bone strength, in rabbits. Calcif. Tissue Int. 1997, 61, 77-83. [CrossRef]

124. Lau, W.K.H.; Farley, J.R.; Freeman, T.K.; Baylink, D.J. A proposed mechanism of the mitogenic action of fluoride on bone cells: Inhibition of the activity of osteoblastic acid phosphatase. Metabolism 1989, 38, 858-863.

125. Ammann, P.; Rizzoli, R.; Caverzasio, J.; Bonjour, J.P. Fluoride potentiates the osteogenic effects of IGF-I in aged ovariectomized rats. Bone 1998, 22, 39-43. [CrossRef]

126. McCarthy, T.L.; Centrella, M.; Raisz, L.G.; Canalis, E. Prostaglandin E2 stimulates insulin-like growth factor I synthesis in osteoblast-enriched cultures from fetal rat bone. Endocrinology 1991, 128, 2895-2900. [CrossRef]

127. DiBattista, J.A.; Martel-Pelletier, J.; Wosu, L.O.; Sandor, T.; Antakly, T.; Pelletier, J.P. Glucocorticoid receptor mediated inhibition of interleukin-1 stimulated neutral metalloprotease synthesis in normal human chondrocytes. J. Clin. Endocrinol. Metab. 1991, 72, 316-326. [CrossRef]

128. Raisz, L.G.; Fall, P.M.; Gabbitas, B.Y.; McCarthy, T.L.; Kream, B.E.; Canalis, E. Effects of prostaglandin Ez on bone formation in cultured fetal rat calvariae: Role of insulin- like growth factor I. Endocrinology 1993, 133, 1504-1510. [CrossRef]

129. Bichell, D.P.; Rotwein, P.; McCarthy, T.L. Prostaglandin E2 rapidly stimulates insulin-like growth factor I gene expression in primary rat osteoblast cultures: Evidence for transcriptional control. Endocrinology 1993, 133, 1020-1028. [CrossRef]

130. Fournier, T.; Riches, D.W.; Winston, B.W.; Rose, D.M.; Young, S.K.; Noble, P.W.; Lake, F.R.; Henson, P.M. Divergence in macrophage insulin-like growth factor-I (IGF-I) synthesis induced by TNF-alpha and prostaglandin E2. J. Immunol. 1995, 155, 2123-2133.

131. Gutowska, I.; Baranowska-Bosiacka, I.; Siennicka, A.; Bakiewicz, M.; Machaliński, B.; Stachowska, E.; Chlube, D. Fluoride and generation of pro-inflammatory factors in human macrophages. Fluoride 2011, 44, 125-134. 
132. Gutowska, I.; Baranowska-Bosiacka, I.; Siennicka, A.; Telesiński, A.; Stańczyk-Dunaj, M.; Wesołowska, T.; Gąssowska, M.; Kłos, P.; Zakrzewska, H.; Machaliński, B.; et al. Activation of phospholipase A2 by low levels of fluoride in THP1 macrophages via altered $\mathrm{Ca}^{2+}$ and cAMP concentration. Prostaglandins Leukot. Essent. Fatty Acids 2012, 86, 99-105. [CrossRef]

133. Gutowska, I.; Baranowska-Bosiacka, I.; Goschorska, M.; Kolasa, A.; Łukomska, A.; Jakubczyk, K.; Dec, K.; Chlubek, D. Fluoride as a factor initiating and potentiating inflammation in THP1 differentiated monocytes/macrophages. Toxicol. In Vitro 2015, 29, 1661-1668. [CrossRef]

134. Yan, N.; Liu, Y.; Liu, S. Fluoride-Induced Neuron Apoptosis and Expressions of Inflammatory Factors by Activating Microglia in Rat Brain. Mol. Neurobiol. 2016, 53, 4449-4460. [CrossRef]

135. Thangapandiyan, S.; Miltonprabu, S. Epigallocatechin gallate supplementation protects against renal injury induced by fluoride intoxication in rats: Role of Nrf2/HO-1 signaling. Toxicol. Rep. 2014, 1, 12-30. [CrossRef]

136. Thangapandiyan, S.; Miltonprabu, S. Epigallocatechin gallate exacerbates fluoride-induced oxidative stress mediated testicular toxicity in rats through the activation of Nrf2 signaling pathway. Asian Pac. J. Reprod. 2015, 4, 272-287. [CrossRef]

137. Liu, J.; Xia, T.; Zhang, M.; He, W.; He, P.; Chen, X.; Yang, K.; Wang, A. Screening of Environmental Response Genes Related to Dental Fluorosis. Fluoride 2006, 39, 195-201.

138. Refsnes, M.; Becher, R.; Lâg, M. Fluoride-induced interleukin- 6 and interleukin- 8 synthesis in human epithelial lung cells. Hum. Exp. Toxicol. 1999, 18, 645-652. [CrossRef]

139. Shanmugam, T.; Abdulla, S.; Yakulasamy, V.; Selvaraj, M.; Mathan, R. A mechanism underlying the neurotoxicity induced by sodium fluoride and its reversal by epigallocatechin gallate in the rat hippocampus: Involvement of NrF2/Keap-1 signaling pathway. J. Basic Appl. Zool. 2018, 79, 17. [CrossRef]

140. Zhou, B.H.; Tan, P.P.; Jia, L.S.; Zhao, W.P.; Wang, J.C.; Wang, H.W. PI3K/AKT signaling pathway involvement in fluoride-induced apoptosis in $\mathrm{C}_{2} \mathrm{C}_{12}$ cells. Chemosphere 2018, 199, 297-302. [CrossRef]

141. Fan, B.; Yu, Y.; Zhang, Y. PI3K-Akt1 expression and its significance in liver tissues with chronic fluorosis. Int. J. Clin. Exp. Pathol. 2015, 8, 1226-1236.

142. Kanagaraj, V.V.; Panneerselvam, L.; Govindarajan, V.; Ameeramja, J.; Perumal, E. Caffeic acid, a phyto polyphenol mitigates fluoride induced hepatotoxicity in rats: A possible mechanism. Biofactors 2015, 41, 90-100. [CrossRef]

143. Yu, Y.N.; Yang, D.; Zhu, H.Z.; Deng, C.N.; Guan, Z.Z. Expression of mRNA and protein of p38, Osx, PI3K and Akt1 in rat bone with chronic fluorosis. Chin. J. Pathol. 2012, 41, 622-626.

144. Zhu, H.Z.; Yu, Y.N.; Deng, C.N.; Yang, D. Effect of fluoride on expression of phosphoinositide 3-kinase, protein kinase B1 mRNA and protein in bone tissue of rats. Chin. J. Endemiol. 2011, 30, 261-265.

145. Lv, Y.G.; Kang, L.; Wu, G. Fluorosis increases the risk of postmenopausal osteoporosis by stimulating interferon $\gamma$. Biochem. Biophys. Res. Commun. 2016, 479, 372-379. [CrossRef] [PubMed]

146. Zhao, Y.; Li, Y.; Gao, Y.; Yuan, M.; Manthari, R.K.; Wang, J.; Wang, J. TGF- $\beta 1$ acts as mediator in fluoride-induced autophagy in the mouse osteoblast cells. Food Chem. Toxicol. 2018, 115, 26-33. [CrossRef]

147. Sakallioğlu, E.E.; Muğlali, M.; Baş, B.M.; Gulbahar, Y.; Lütfioğlu, M.; Aksoye, A. Effects of Excessive Fluoride intake on Bone Turnover in Mandible: An Immunohistochemical Study in Rabbits. Fluoride 2014, 47, $23-30$.

148. Gao, Y.H.; Fu, S.B.; Sun, H.; Zhou, L.W.; Sun, D.J. Expression of the transforming growth factor- $\beta$ superfamily in bone turnover of fluorosis. Chin. J. Endemiol. 2006, 25, 374-378.

149. Yang, C.; Wang, Y.; Xu, H. Fluoride Regulate Osteoblastic Transforming Growth Factor- $\beta 1$ Signaling by Mediating Recycling of the Type I Receptor ALK5. PLoS ONE 2017, 12, e0170674.

150. Liu, X.L.; Song, J.; Liu, K.J.; Wang, W.P.; Xu, C.; Zhang, Y.Z.; Liu, Y. Role of inhibition of osteogenesis function by Sema4D/Plexin-B1 signaling pathway in skeletal fluorosis in vitro. J. Huazhong Univ. Sci. Technol. Med. Sci. 2015, 35, 712-715. [CrossRef] [PubMed]

151. Wang, Y.Q.; Yuan, R.; Sun, Y.P.; Lee, T.J.; Shah, G.V. Antiproliferative action of calcitonin on lactotrophs of the rat anterior pituitary gland: Evidence for the involvement of transforming growth factor beta 1 in calcitonin action. Endocrinology 2003, 144, 2164-2171. [CrossRef]

152. Krishnamachari, K.A.V.R.; Sivakumar, B. Endemic genu valgum. A new dimension to the fluorosis problem in India. Fluoride 1976, 9, 185-200.

153. Teotia, S.P.S.; Teotia, M.; Singh, R.K.; Teotia, N.P.S.; Taves, D.R.; Heels, S. Plasma fluoride, 25-hydroxycholecalciferol, immunoreactive parathyroid Hormone and calcitonin in patients with endemic skeletal fluorosis. Fluoride 1978, 11, 115-119. 
154. Ma, J.; Li, M.; Song, Y.; Tu, J.; Liu, F.; Liu, K. Serum Osteocalcin and Calcitonin in adult males with different fluoride exposures. Fluoride 2009, 42, 133-136.

155. Chen, S.; Li, B.; Lin, S.; Huang, Y.; Zhao, X.; Zhang, M.; Xia, Y.; Fang, X.; Wang, J.; Hwang, S.A.; et al. Change of urinary fluoride and bone metabolism indicators in the endemic fluorosis areas of southern china after supplying low fluoride public water. Public Health 2013, 13, 15. [CrossRef]

156. Shashi, A.; Singla, S. Parathyroid Function in Osteofluorosis. World J. Med. Sci. 2013, 8, 67-73.

157. Ba, Y.; Zhu, J.Y.; Yang, Y.J.; Yu, B.; Huang, H.; Wang, G.; Ren, L.J.; Cheng, X.M.; Cui, L.X.; Zhang, Y.W. Serum calciotropic hormone levels, and dental fluorisis in children exposed to different concentrations of fluoride and iodine in drinking water. Chin. Med. J. 2010, 123, 675-679. [PubMed]

158. Xu, Y.; Yuan, S.; Xie, Q. Effects of Fluorosis on induced secretion of rat Prolactin in vivo and in vitro. Fluoride $1997,30,173-178$.

159. Ortiz-Pérez, D.; Rodríguez-Martínez, M.; Martínez, F.; Borja-Aburto, V.H.; Castelo, J.; Grimaldo, J.I.; de la Cruz, E.; Carrizales, L.; Díaz-Barriga, F. Fluoride-induced disruption of reproductive hormones in men. Environ. Res. 2003, 93, 20-30. [CrossRef]

160. Murugan, A.; Subramanian, A. Studies on the Biological Effects of Fluoride Intoxication in Dental Fluorosis Cases. Aust. J. Basic Appl. Sci. 2011, 5, 1362-1367.

161. Shah, G.V.; Wang, W.; Grosvenor, C.E.; Crowley, W.R. Calcitonin inhibits basal and thyrotropin-releasing hormone-induced release of prolactin from anterior pituitary cells: Evidence for a selective action exerted proximal to secretagogue-induced increases in cytosolic $\mathrm{Ca}^{2+}$. Endocrinology 1990, 127, 621-628. [CrossRef]

162. Martin, T.F. Calcitonin peptide inhibition of TRH-stimulated prolactin secretion Additional evidence for inhibitory regulation of phospholipase C. Trends Endocrinol. Metab. 1992, 3, 82-85. [CrossRef]

163. Shah, G.V.; Pedchenko, V.; Stanley, S.; Li, Z.; Samson, W.K. Calcitonin is a physiological inhibitor of prolactin secretion in ovariectomized female rats. Endocrinology 1996, 137, 1814-1822. [CrossRef]

164. Shah, G.V.; Chien, J.; Sun, Y.P.; Puri, S.; Ravindra, R. Calcitonin inhibits anterior pituitary cell proliferation in the adult female rats. Endocrinology 1999, 140, 4281-4291. [CrossRef]

165. Zhang, S.; Zhang, X.; Liu, H.; Qu, W.; Guan, Z.; Zeng, Q.; Jiang, C.; Gao, H.; Zhang, C.; Lei, R.; et al. Modifying Effect of COMT Gene Polymorphism and a Predictive Role for Proteomics Analysis in Children's Intelligence in Endemic Fluorosis Area in Tianjin, China. Toxicol. Sci. 2015, 144, 238-245. [CrossRef]

166. Yasmin, S.; Ranjan, S.; D'Souza, D.; D'Souza, H. Effect of excess fluoride ingestion on human thyroid function in Gaya region, Bihar, India. Toxicol. Environ. Chem. 2013, 95, 1235-1243. [CrossRef]

167. Hosur, M.B.; Puranik, R.S.; Vanaki, S.; Puranik, S. Study of thyroid hormones free triiodothyronine (FT3), free thyroxine (FT4) and thyroid stimulating hormone (TSH) in subjects with dental fluorosis. Eur. J. Dent. 2012, 6, 184-190. [PubMed]

168. Karademir, S.; Mustafa, A.; Kuybulu, A.E.; Olgar, S.; Öktem, F. Effects of fluorosis on QT dispersion, heart rate variability and echocardiographic parameters in children. Anadolu Kardiyol. Derg. 2011, 1, 150-155. [CrossRef] [PubMed]

169. Xiang, Q.; Chen, L.; Miang, Y.; Wu, M.; Chen, B. Fluoride and thyroid function in children in two villages in China. J. Toxicol. Environ. Health Sci. 2009, 1, 054-059.

170. Bahijri, S.M.; Al-Fares, A.; Al-Khateeb, T.; Mufti, A.B. Hyperparathyroidism and Hypothyroidism in Individuals Consuming High Fluoride Intake in Jeddah-Saudi Arabia. Syrian Clin. Lab. Assoc. 2008, 4, 1428-1436.

171. Jun, D.; Ying, W. Clinical Application of Determination of Serum Thyroid Hormones (TSH, T3, T4, FT3, FT4) Levels in Elderly Patients with Chronic Diseases. J. Radioimmunol. 2006, 03. Available online: http: / / en.cnki.com.cn/Article_en/CJFDTOTAL-FSMY200603057.htm (accessed on 19 January 2019).

172. Ruiz-Payan, A. Chronic Effects of Fluoride on Growth, Blood Chemistry and Thyroid Hormones in Adolescents Residing in Three Communities in Northern Mexico; AAI3214004; ETD Collection for University of Texas: El Paso, TX, USA, 2006.

173. Wang, X.; Wang, L.; Hu, P.; Guo, X.; Luo, X. Effects of high iodine and high fluorine on children's intelligence and thyroid function. Chin. J. Endemiol. 2001, 20, 288-290.

174. Xiaoli, L.; Zhongxue, F.; Jili, H.; Qinlan, W.; Hongyin, W. The Detection of Children's T3, T4 and TSH Contents in Endemic Fluorosis Area. Endem. Dis. Bull. 1999, 14, 16-17.

175. Yao, Y.; Zhou, J.; Wang, X.; Cui, Q.; Lin, F. Analysis on the Correlation between TSH and intelligence level of children with Dental Fluorosis from Endemic Fluorosis Regions. Lit. Inf. Prev. Med. 1996, 2, $26-27$. 
176. Liu, Z.; Min, H.; Hanwen, W. An Investigation on the Serum Thyroid Hormones and Fluoride Concentrations in Patients with Endemic Fluorosis. Chin. J. Endemiol. 1988, 7, 216-218.

177. Bachinskii, P.P.; Gutsalenko, O.A.; Naryzhniuk, N.D.; Sidora, V.D.; Shliakhta, A.I. Action of the body fluorine of healthy persons and thyroidopathy patients on the function of hypophyseal-thyroid the system. Probl. Endokrinol. 1985, 31, 25-29.

178. Yanni, Y. Study on serum T4, T3 and TSH levels in patients with chronic skeletal fluorosis. Chin. J. Endemiol. 1985, 4, 242-243.

179. Uller, R.P.; Van Herle, A.J.; Chopra, I.J. Comparison of alterations in circulating thyroglobulin, triiodothyronine and thyroxine in response to exogenous (bovine) and endogenous (human) thyrotropin. J. Clin. Endocrinol. Metab. 1973, 37, 741-745. [CrossRef] [PubMed]

180. Lo Gerfo, P.; Colacchio, T.A.; Colacchio, D.A.; Feind, C.R. Effect of TSH stimulation on serum thyroglobulin in metastatic thyroid cancer. J. Surg. Oncol. 1980, 14, 195-200. [CrossRef] [PubMed]

181. Sato, K.; Okamura, K.; Ikenoue, H.; Shiroozu, A.; Yoshinari, M.; Fujishima, M. TSH dependent elevation of serum thyroglobulin in reversible primary hypothyroidism. Clin. Endocrinol. 1988, 29, 231-237. [CrossRef]

182. Sanai, T.; Okamura, K.; Rikitake, S.; Fukuda, M.; Onozawa, K.; Sanematsu, M.; Takashima, T.; Miyazono, M.; Ikeda, Y. The high prevalence of reversible subclinical hypothyroidism with elevated serum thyroglobulin levels in chronic kidney disease patients. Clin. Nephrol. 2017, 87, 237-244. [CrossRef]

183. Giovanella, L.; Imperiali, M.; Ferrari, A.; Palumbo, A.; Furlani, L.; Graziani, M.S.; Castello, R. Serum thyroglobulin reference values according to NACB criteria in healthy subjects with normal thyroid ultrasound. Clin. Chem. Lab. Med. 2012, 50, 891-893. [CrossRef] [PubMed]

184. Laurberg, P.; Pedersen, K.M. A sensitive radio-immunoassay for serum thyroglobulin-including a correct screening for thyroglobulin autoantibodies. Scand. J. Clin. Lab. Investig. 1987, 47, 685-689. [CrossRef]

185. Cahoon, E.K.; Rozhko, A.; Hatch, M.; Polyanskaya, O.; Ostroumova, E.; Tang, M.; Nadirov, E.; Yauseyenka, V.; Savasteeva, I.; McConnell, R.J.; et al. Factors associated with serum thyroglobulin levels in a population living in Belarus. Clin. Endocrinol. 2013, 79, 120-127. [CrossRef] [PubMed]

186. Furlanetto, T.W.; Nguyen, L.Q.; Jameson, J.L. Estradiol increases proliferation and down-regulates the sodium/iodide symporter gene in FRTL-5 cells. Endocrinology 1999, 140, 5705-5711. [CrossRef] [PubMed]

187. Gietka-Czernel, M. The thyroid gland in postmenopausal women: Physiology and diseases. Prz. Menopauzalny 2017, 16, 33-37. [CrossRef] [PubMed]

188. Schindler, A.E. Thyroid function and postmenopause. Gynecol. Endocrinol. 2003, 17, 79-85. [CrossRef]

189. Bordoloi, G.; Jahan, W. A study of thyroid function in premenopausal and postmenopausal women of Dibrugarh town, Assam, India. Int. J. Res. Med. Sci. 2018, 6, 3015-3019. [CrossRef]

190. Garg, N.; Sodhi, K.; Singh, J.; Badyal, A. Evaluation of subclinical hypothyroidism in women of postmenopausal age group. J. Adv. Res. Biol. Sci. 2014, 4, 20-22.

191. Kapadia, N.A.; Mehta, N. Comparison of thyroid profile in premenopausal and postmenopausal women. Int. J. Basic Appl. Physiol. 2017, 6, 150-154.

192. Husdan, H.; Vogi, R.; Oreopoulos, D.; Gryfe, C.; Rapoport, A. Serum Ionic Fluoride: Normal Range and Relationship to Age and Sex. Clin. Chem. 1976, 22, 1884-1888.

193. Kataraki, P.; Rao, P. Fluoride and oxidative stress in postmenopausal women. IOSR J. Pharm. 2012, 2, 57-59. [CrossRef]

194. Itai, K.; Onoda, T.; Nohara, M.; Ohsawa, M.; Tanno, K.; Sato, T.; Kuribayashi, T.; Okayama, A. Serum ionic fluoride concentrations are related to renal function and menopause status but not to age in a Japanese general population. Clin. Chim. Acta 2010, 411, 263-266. [CrossRef]

195. Santisteban, P.; Kohn, L.D.; Di Lauro, R. Thyroglobulin gene expression is regulated by insulin and insulin-like growth factor 1, as well as thyrotropin, in FRTL-5 thyroid cell. J. Biol. Chem. 1987, 262, 4048-4052. [PubMed]

196. Medina, D.L.; Suzuki, K.; Pietrarelli, M.; Okajima, F.; Kohn, L.D.; Santisteban, P. Role of insulin and serum on thyrotropin regulation of thyroid transcription factor- 1 and pax- 8 genes expression in FRTL- 5 thyroid cells. Thyroid 2000, 10, 295-303. [CrossRef] [PubMed]

197. Kanazawa, I. Osteocalcin as a hormone regulating glucose metabolism. World J. Diabetes 2015, 6, $1345-1354$. [CrossRef] [PubMed] 
198. Rui, X.; Xu, B.; Su, J.; Pan, C.; Zhan, C.; Su, B.; Li, H.; Wang, J.; Sheng, H.; Qu, S. Differential pattern for regulating insulin secretion, insulin resistance, and lipid metabolism by osteocalcin in male and female T2DM patients. Med. Sci. Monit. 2014, 20, 711-719.

199. Kanazawa, I.; Yamaguchi, T.; Tada, Y.; Yamauchi, M.; Yano, S.; Sugimoto, T. Serum osteocalcin level is positively associated with insulin sensitivity and secretion in patients with type 2 diabetes. Bone 2011, 48, 720-725. [CrossRef]

200. Aoki, A.; Muneyuki, T.; Yoshida, M.; Munakata, H.; Ishikawa, S.E.; Sugawara, H.; Kawakami, M.; Kakei, M. Circulating osteocalcin is increased in early-stage diabetes. Diabetes Res. Clin. Pract. 2011, 92, 181-186. [CrossRef]

201. Winhofer, Y.; Handisurya, A.; Tura, A.; Bittighofer, C.; Klein, K.; Schneider, B.; Bieglmayer, C.; Wagner, O.F.; Pacini, G.; Luger, A.; et al. Osteocalcin Is Related to Enhanced Insulin Secretion in Gestational Diabetes Mellitus. Diabetes Care 2010, 33, 139-143. [CrossRef] [PubMed]

202. Fernandez-Real, J.M.; Izquierdo, M.; Ortega, F.; Gorostiaga, E.; Gómez-Ambrosi, J.; Moreno-Navarrete, J.M.; Frühbeck, G.; Martínez, C.; Idoate, F.; Salvador, J.; et al. The relationship of serum osteocalcin concentration to insulin secretion, sensitivity, and disposal with hypocaloric diet and resistance training. J. Clin. Endocrinol. Metab. 2009, 94, 237-245. [CrossRef] [PubMed]

203. Ferron, M.; Hinoi, E.; Karsenty, G.; Ducy, P. Osteocalcin differentially regulates $\beta$ cell and adipocyte gene expression and affects the development of metabolic diseases in wild-type mice. Proc. Natl. Acad. Sci. USA 2008, 105, 5266-5270. [CrossRef]

204. Mizokami, A.; Yasutake, Y.; Gao, J.; Matsuda, M.; Takahashi, I.; Takeuchi, H.; Hirata, M. Osteocalcin induces release of glucagon-like peptide-1 and thereby stimulates insulin secretion in mice. PLoS ONE 2013, 8, e57375. [CrossRef] [PubMed]

205. Mizokami, A.; Yasutake, Y.; Higashi, S.; Kawakubo-Yasukochi, T.; Chishaki, S.; Takahashi, I.; Takeuchi, H.; Hirata, M. Oral administration of osteocalcin improves glucose utilization by stimulating glucagon-like peptide-1 secretion. Bone 2014, 69, 68-79. [CrossRef] [PubMed]

206. Srivastava, R.N.; Gill, D.S.; Moudgil, A.; Menon, R.K.; Thomas, M.; Dandona, P. Normal ionized calcium, parathyroid hypersecretion, and elevated osteocalcin in a family with fluorosis. Metabolism 1989, 38, 120-124. [CrossRef]

207. Bouletreau, P.H.; Bost, M.; Fontanges, E.; Lauverjat, M.; Gutknecht, C.; Ecochard, R.; Delmas, P.D.; Chambrier, $\mathrm{C}$. Fluoride exposure and bone status in patients with chronic intestinal failure who are receiving home parenteral nutrition. Am. J. Clin. Nutr. 2006, 83, 1429-1437. [CrossRef]

208. Battmann, A.; Resch, H.; Libanati, C.R.; Ludy, D.; Fischer, M.; Farley, S.; Baylink, D.J. Serum Fluoride and Serum Osteocalcin Levels in Response to a Novel Sustained-Release Monofluorophosphate Preparation: Comparison with Plain Monofluorophosphate. Osteoporosis Int. 1997, 7, 48-51. [CrossRef]

209. Huang, H.; Ba, Y.; Cui, L.; Cheng, X.; Zhu, J.; Zhang, Y.; Yan, P.; Zhu, C.; Kilfoy, B.; Zhang, Y. COLIA2 gene polymorphisms (Pvu II and RSA I), serum calcitropic hormone levels, and dental fluorosis. Community Dent. Oral Epidemiol. 2008, 36, 517-522. [CrossRef]

210. Dandona, P.; Coumar, A.; Gill, D.S.; Bell, J.; Thomas, M. Sodium Fluoride Stimulates Osteocalcin in Normal Subjects. Clin. Endocrinol. 1988, 29, 437-441. [CrossRef]

211. Pereira, A.G.; Chiba, F.Y.; de Lima Coutinho Mattera, M.S.; Pereira, R.F.; de Cássia Alves Nunes, R.; Tsosura, T.V.S.; Okamoto, R.; Sumida, D.H. Effects of fluoride on insulin signaling and bone metabolism in ovariectomized rats. J. Trace Elem. Med. Biol. 2017, 39, 140-146. [CrossRef] [PubMed]

212. Rogalska, A.; Kuter, K.; Żelazko, A.; Glogowska-Gruszka, A.; Świętochowska, E.; Nowak, P. Fluoride Alteration of $[3 \mathrm{H}]$ Glucose Uptake in Wistar Rat Brain and Peripheral Tissues. Neurotox. Res. 2017, 31, 436-443. [CrossRef]

213. Validandi, V.; Gourineni, S.R.; Dheeravath, S.; Nagalla, B.; Khandare, A.L. Tamarind Supplementation Ameliorates Fluoride-induced Glucose Intolerance and Insulin Resistance in Rats. Fluoride 2017, 50, 314-323.

214. Hu, C.Y.; Ren, L.Q.; Li, X.N.; Wu, N.; Li, G.S.; Liu, Q.Y.; Xu, H. Effect of fluoride on insulin level of rats and insulin receptor expression in the MC3T3-E1 cells. Biol. Trace Elem. Res. 2012, 150, 297-305. [CrossRef] [PubMed]

215. Lupo, M.; Afonso, M.; Buzalaf, R.; Rigalli, A. Effect of Fluoridated Water on Plasma Insulin Levels and Glucose Homeostasis in Rats with Renal Deficiency. Biol. Trace Elem. Res. 2011, 140, 198-207. [CrossRef] [PubMed] 
216. Trivedi, N.; Mithal, A.; Gupta, S.K.; Godbole, M.M. Reversible impairment of glucose tolerance in patients with endemic fluorosis. Fluoride Collaborative Study Group. Diabetologia 1993, 36, 826-828. [CrossRef] [PubMed]

217. Cárdenas-González, M.; Jacobo Estrada, T.; Rodríguez-Muñoz, R.; Barrera-Chimal, J.; Bobadilla, N.A.; Barbier, O.C.; Del Razo, L.M. Sub-chronic exposure to fluoride impacts the response to a subsequent nephrotoxic treatment with gentamicin. J. Appl. Toxicol. 2016, 36, 309-319. [CrossRef]

218. Tojo, A.; Onozato, M.L.; Ha, H.; Kurihara, H.; Sakai, T.; Goto, A.; Fujita, T.; Endou, H. Reduced albumin reabsorption in the proximal tubule of early-stage diabetic rats. Histochem. Cell Biol. 2001, 116, 269-276. [CrossRef] [PubMed]

219. Peruchetti, D.B.; Silva-Aguiar, R.P.; Siqueira, G.M.; Dias, W.B.; Caruso-Neves, C. High glucose reduces megalin-mediated albumin endocytosis in renal proximal tubule cells through protein kinase B O-GlcNAcylation. J. Biol. Chem. 2018, 293, 11388-11400. [CrossRef] [PubMed]

220. Wang, J.Y.; Yang, J.H.; Xu, J.; Jia, J.Y.; Zhang, X.R.; Yue, X.D.; Chen, L.M.; Shan, C.Y.; Zheng, M.Y.; Han, F.; et al. Renal tubular damage may contribute more to acute hyperglycemia induced kidney injury in non-diabetic conscious rats. J. Diabetes Complicat. 2015, 29, 621-628. [CrossRef] [PubMed]

221. Guan, Z.; Yang, P.; Yu, N.; Zhuang, Z. An Experimental study of blood biochemical diagnostic indices for chronic fluorosis. Fluoride 1989, 22, 108-111.

222. Shanthakumari, D.; Subramanian, S. Effect of Fluoride Intoxication on Bone Tissue of Experimental Rats. Res. J. Environ. Sci. 2007, 1, 82-92.

223. Suketa, Y.; Asao, Y.; Kanamoto, Y.; Shakashita, T.; Okada, S. Changes in adrenal function as a possible mechanism for elevation of serum glucose by single large dose of fluoride. Toxicol. Appl. Pharmacol. 1985, 80, 199-205. [CrossRef]

224. Rigalli, A.; Ballina, J.C.; Roveri, E.; Puche, R.C. Inhibitory effect of fluoride on the secretion of Insulin. Calcif. Tissue Int. 1990, 46, 333-338. [CrossRef]

225. Grucka-Mamczar, E.; Birkner, E.; Kasperczyk, S.; Kasperczyk, A.; Chlubek, D.; Samujło, D.; Cegłowska, A. Lipid Balance in rats with fluoride-induced hyperglycemia. Fluoride 2004, 37, 195-200.

226. McGown, E.L.; Suttie, J.W. Mechanism of fluoride-induced hyperglycemia in the Rat. Toxicol. Appl. Pharmacol. 1977, 40, 83-90. [CrossRef]

227. Allmann, D.W.; Kleiner, H.S. Effect of NaF on Rat Tissue cAMP levels in vivo. Pharmacol. Ther. Dent. 1980, 5, 73-78.

228. Grucka-Mamczar, E.; Birkner, E.; Zalejska-Fiolka, J.; Machoy, Z. Disturbances of kidney function in rats with fluoride-induced hyperglycemia after acute poisoning by fluoride. Fluoride 2005, 38, 48-51.

229. Szymafiska, H.; Mandat, A.; Jaroszewicz-Heigelmann, H.; Szymadski, Z.; Holicki, M.; Neuman, Z.; Ruszkowska, A. The results of assorted investigations carried out in workers exposed to Fluorine compounds. Metabolism of Fluorine. Societas Scientiarum Stetinensis. PWN Warszawa-Poznafi. 1982, 96-102.

230. Chlubek, D.; Grucka-Mamczar, E.; Birkner, E.; Polaniak, R.; Stawiarska-Pieta, B.; Duliban, H. Activity of pancreatic antioxidative enzymes and malondialdehyde concentrations in rats with hyperglycemia caused by fluoride intoxication. J. Trace Elem. Med. Biol. 2003, 17, 57-60. [CrossRef]

231. Rupal, A.V.; Dhrutigna, R.K.; Krutika, L.B.; Narasimhacharya, A.V.R.L. Therapeutic benefits of glibenclamide in fluoride intoxicated diabetic rats. Fluoride 2010, 43, 141-149.

232. García-Montalvo, E.A.; Reyes-Pérez, H.; Del Razo, L.M. Fluoride exposure impairs glucose tolerance via decreased insulin expression and oxidative stress. Toxicology 2009, 263, 75-83. [CrossRef]

233. Grucka-Mamczar, E.; Birkner, E.; Zalejska-Fiolka, J.; Machoy, Z.; Kasperczyk, S.; Blaszczyk, I. Influence of extended exposure to sodium fluoride and caffeine on the activity of carbohydrate metabolism enzymes in rat blood serum and liver. Fluoride 2007, 40, 62-66.

234. Sakurai, T.; Suzuki, K.; Taki, T.; Suketa, V.T. The mechanism of changes in metabolism and transport of glucose caused by fluoride administration to rats. Fluoride 1993, 26, 210.

235. Peters, J.P.; Man, E.B. The relation of albumin to precipitable iodine of serum. J. Clin. Investig. 1948, 27, 397-405. [CrossRef] [PubMed]

236. Riggs, D.S.; Lavietes, P.H.; Man, E.B. Investigations on the nature of blood iodine. J. Biol. Chem. 1942, 143, 363-372.

237. Roholm, K. Fluorine Intoxication, a Clinical-Hygienic Study with a Review of the Literature and Some Experimental Investigations; H.K. Lewis \& Co.: London, UK, 1937. 
238. Jiménez-Córdova, M.I.; Cárdenas-González, M.; Aguilar-Madrid, G.; Sanchez-Peña, L.C.; Barrera-Hernández, Á.; Domínguez-Guerrero, I.A.; González-Horta, C.; Barbier, O.C.; Del Razo, L.M. Evaluation of kidney injury biomarkers in an adult Mexican population environmentally exposed to fluoride and low arsenic levels. Toxicol. Appl. Pharmacol. 2018, 352, 97-106. [CrossRef]

239. Kumar, S.P.; Harper, R.A. Fluorosis in Aden. Br. J. Radiol. 1963, 36, 497-502. [CrossRef]

240. Susheela, A.K.; Jethanandani, P. Serum haptoglobin and C-reactive protein in human skeletal fluorosis. Clin. Biochem. 1994, 27, 463-468. [CrossRef]

241. Shivashankara, A.R.; Shivarajashankara, Y.M.; Rao, S.H.; Bhat, G.P. A clinical and biochemical study of chronic fluoride toxicity in children of Kheru Thanda of Gulbarga District, Karnataka, India. Fluoride 2000, 33, 66-73.

242. Subramanian, V.S.; Priya, V.V.; Gayathri, R. Estimation of salivary total protein and albumin in dental fluorosis patient. Drug Invent. Today 2018, 10, 1734-1736.

243. Awdeh, Z.L.; Islam, M.R.; Samra, S.A. Variations in the level of human serum albumin during glucose tolerance test. Biochem. Biophys. Res. Commun. 1974, 56, 358-362. [CrossRef]

244. Thrailkill, K.M.; Nimmo, T.; Bunn, R.C.; Cockrell, G.E.; Moreau, C.S.; Mackintosh, S.; Edmondson, R.D.; Fowlkes, J.L. Microalbuminuria in type 1 diabetes mellitus is associated with enhanced excretion of the endocytic, multiligand receptors megalin and cubilin. Diabetes Care 2009, 32, 1266-1268. [CrossRef] [PubMed]

245. De la Vieja, A.; Santisteban, P. Role of iodide metabolism in physiology and cancer. Endocr. Relat. Cancer 2018, 25, R225-R245. [CrossRef]

246. Garg, L.C.; Tisher, C.C. Effects of thyroid hormone on Na-K-adenosine triphosphatase activity along the rat nephron. J. Lab. Clin. Med. 1985, 106, 568-572.

247. Levy, O.; Dai, G.; Riedel, C.; Ginter, C.S.; Paul, E.M.; Lebowitz, A.N.; Carrasco, N. Characterization of the thyroid $\mathrm{Na}^{+} / \mathrm{I}^{-}$symporter with an anti-COOH terminus antibody. Proc. Natl. Acad. Sci. USA 1997, 94, 5568-5573. [CrossRef]

248. Paire, A.; Bernier-Valentin, F.; Selmi-Ruby, S.; Rousset, B. Characterization of the rat thyroid iodide transporter using anti-peptide antibodies. Relationship between its expression and activity. J. Biol. Chem. 1997, 272, 18245-18249. [CrossRef]

249. Kogai, T.; Endo, T.; Saito, T.; Miyazaki, A.; Kawaguchi, A.; Onaya, T. Regulation by thyroid-stimulating hormone of sodium/iodide symporter gene expression and protein levels in FRTL-5 cells. Endocrinology 1997, 138, 2227-2232. [CrossRef]

250. Saito, T.; Endo, T.; Kawaguchi, A.; Ikeda, M.; Nakazato, M.; Kogai, T.; Onaya, T. Increased expression of the $\mathrm{Na}^{+} / \mathrm{I}^{-}$symporter in cultured human thyroid cells exposed to thyrotropin and in Graves' thyroid tissue. J. Clin. Endocrinol. Metab. 1997, 82, 3331-3336. [CrossRef] [PubMed]

251. Ward, L.S.; Santarosa, P.L.; Granja, F.; da Assumpção, L.V.M.; Savoldi, M.; Goldman, G.H. Low expression of sodium iodide symporter identifies aggressive thyroid tumors. Cancer Lett. 2003, 200, 85-91. [CrossRef]

252. Scipioni, A.; Ferretti, E.; Soda, G.; Tosi, E.; Bruno, R.; Costante, G.; Meringolo, D.; Arturi, F.; Durante, C.; Amorosi, A.; et al. hNIS protein in thyroid: The iodine supply influences its expression and localization. Thyroid 2007, 17, 613-618. [CrossRef] [PubMed]

253. World Health Organization. Fluorides and Oral Health; Technical Report Series-846; WHO: Geneva, Switzerland, 1984.

254. Beltrán-Aguilar, E.D.; Barker, L.; Dye, B.A. Prevalence and severity of dental fluorosis in the United States, 1999-2004. NCHS Data Brief 2010, 1-8.

255. Marshall, T.A.; Levy, S.M.; Warren, J.J.; Broffitt, B.; Eichenberger-Gilmore, J.M.; Stumbo, P.J. Associations between Intakes of Fluoride from Beverages during Infancy and Dental Fluorosis of Primary Teeth. J. Am. Coll. Nutr. 2004, 23, 108-116. [CrossRef]

256. Whelton, H.; Crowley, E.; O’Mullane, D.; Donaldson, M.; Kelleher, V.; Cronin, M. Dental caries and enamel fluorosis among the fluoridated and non-fluoridated populations in the Republic of Ireland in 2002. Community Dent. Health 2004, 21, 37-44. [PubMed]

257. Delange, F. The disorders induced by iodine deficiency. Thyroid 1994, 4, 107-128. [CrossRef] [PubMed]

258. Instanes, J.T.; Halmøy, A.; Engeland, A.; Haavik, J.; Furu, K.; Klungsøyr, K. Attention-Deficit/Hyperactivity Disorder in Offspring of Mothers with Inflammatory and Immune System Diseases. Biol. Psychiatry 2017, 81, 452-459. [CrossRef] [PubMed] 
259. Abel, M.H.; Ystrom, E.; Caspersen, I.H.; Meltzer, H.M.; Aase, H.; Torheim, L.E.; Askeland, R.B.; Reichborn-Kjennerud, T.; Brantsæter, A.L. Maternal Iodine Intake and Offspring Attention-Deficit/Hyperactivity Disorder: Results from a Large Prospective Cohort Study. Nutrients 2017, 9, 1239. [CrossRef]

260. Kanık Yüksek, S.; Aycan, Z.; Öner, Ö. Evaluation of Iodine Deficiency in Children with Attention Deficit/Hyperactivity Disorder. J. Clin. Res. Pediatr. Endocrinol. 2016, 8, 61-66. [CrossRef] [PubMed]

261. Konikowska, K.; Regulska-Ilow, B.; Rózańska, D. The influence of components of diet on the symptoms of ADHD in children. Rocz. Panstw. Zakl. Hig. 2012, 63, 127-134. [PubMed]

262. Vermiglio, F.; Lo Presti, V.P.; Moleti, M.; Sidoti, M.; Tortorella, G.; Scaffidi, G.; Castagna, M.G.; Mattina, F.; Violi, M.A.; Crisà, A.; et al. Attention deficit and hyperactivity disorders in the offspring of mothers exposed to mild-moderate iodine deficiency: A possible novel iodine deficiency disorder in developed countries. J. Clin. Endocrinol. Metab. 2004, 89, 6054-6060. [CrossRef]

263. Getahun, D.; Jacobsen, S.J.; Fassett, M.J.; Wing, D.A.; Xiang, A.H.; Chiu, V.Y.; Peltier, M.R. Association between maternal hypothyroidism and autism spectrum disorders in children. Pediatr. Res. 2018, 83, 580-588. [CrossRef]

264. Andersen, S.L.; Laurberg, P.; Wu, C.S.; Olsen, J. Attention deficit hyperactivity disorder and autism spectrum disorder in children born to mothers with thyroid dysfunction: A Danish nationwide cohort study. BJOG 2014, 121, 1365-1374. [CrossRef]

265. Błażewicz, A.; Makarewicz, A.; Korona-Glowniak, I.; Dolliver, W.; Kocjan, R. Iodine in autism spectrum disorders. J. Trace Elem. Med. Biol. 2016, 34, 32-37. [CrossRef]

266. Hamza, R.T.; Hewedi, D.H.; Sallam, M.T. Iodine deficiency in Egyptian autistic children and their mothers: Relation to disease severity. Arch. Med. Res. 2013, 44, 555-561. [CrossRef] [PubMed]

267. Sullivan, K.M. Iodine deficiency as a cause of autism. J. Neurol. Sci. 2009, 276, 202. [CrossRef] [PubMed]

268. Gillberg, I.C.; Gillberg, C.; Kopp, S. Hypothyroidism and autism spectrum disorders. J. Child Psychol. Psychiatry 1992, 33, 531-542. [CrossRef]

269. Andersson, M.; de Benoist, B.; Darnton-Hill, I. (Eds.) WHO, Unicef. In Iodine Deficiency in Europe: A Continuing Public Health Problem; World Health Organization: Geneva, Switzerland, 2007; Available online: https://www.who.int/nutrition/publications/VMNIS_Iodine_deficiency_in_Europe.pdf (accessed on 19 January 2019).

270. Lynn, R.; Vanhanen, T. IQ and the Wealth of Nations; Praeger: Westport, CT, USA, 2012.

271. Yu, X.; Chen, J.; Li, Y.; Liu, H.; Hou, C.; Zeng, Q.; Cui, Y.; Zhao, L.; Li, P.; Zhou, Z.; et al. Threshold effects of moderately excessive fluoride exposure on children's health: A potential association between dental fluorosis and loss of excellent intelligence. Environ. Int. 2018, 118, 116-124. [CrossRef] [PubMed]

272. Razdan, P.; Patthi, B.; Kumar, J.K.; Agnihotri, N.; Chaudhari, P.; Prasad, M. Effect of Fluoride Concentration in Drinking Water on Intelligence Quotient of 12-14-Year-Old Children in Mathura District: A Cross-Sectional Study. J. Int. Soc. Prev. Community Dent. 2017, 7, 252-258. [PubMed]

273. Khan, S.A.; Singh, R.K.; Navit, S.; Chadha, D.; Johri, N.; Navit, P.; Sharma, A.; Bahuguna, R. Relationship Between Dental Fluorosis and Intelligence Quotient of School Going Children in and Around Lucknow District: A Cross-Sectional Study. J. Clin. Diagn. Res. 2015, 9, ZC10-ZC15. [CrossRef] [PubMed]

274. Shivaprakash, P.K.; Ohri, K.; Noorani, H. Relation between dental fluorosis and Intelligence quotient in school children of Bagalkot district. J. Indian Soc. Pedod. Prev. Dent. 2011, 29, 117-120. [CrossRef]

275. Sudhir, K.M.; Chandu, G.N.; Prashant, G.M.; Reddy, S.V.V. Effect of fluoride exposure on Intelligence Quotient (IQ) among 13-15year old school children of known endemic area of fluorosis, Nalgonda District, Andhra Pradesh. J. Indian Assoc. Public Health Dent. 2009, 7, 88-94.

276. Ding, Y.; Gao, Y.; Sun, H.; Han, H.; Wang, W.; Ji, X.; Liu, X.; Sun, D. The relationships between low levels of urine fluoride on children's intelligence, dental fluorosis in endemic fluorosis areas in Hulunbuir, Inner Mongolia, China. J. Hazard. Mater. 2011, 186, 1942-1946. [CrossRef] [PubMed]

277. Das, K.; Mondal, N.K. Dental fluorosis and urinary fluoride concentration as a reflection of fluoride exposure and its impact on IQ level and BMI of children of Laxmisagar, Simlapal Block of Bankura District, W.B., India. Environ. Monit. Assess. 2016, 188, 218. [CrossRef] [PubMed]

278. Bashash, M.; Thomas, D.; Hu, H.; Martinez-Mier, E.A.; Sanchez, B.N.; Basu, N.; Peterson, K.E.; Ettinger, A.S.; Wright, R.; Zhang, Z.; et al. Prenatal Fluoride Exposure and Cognitive Outcomes in Children at 4 and 6-12 Years of Age in Mexico. Environ. Health Perspect. 2017, 125, 097017. [CrossRef] 
279. Bashash, M.; Marchand, M.; Hu, H.; Till, C.; Martinez-Mier, E.A.; Sanchez, B.N.; Basu, N.; Peterson, K.E.; Green, R.; Schnaas, L.; et al. Prenatal fluoride exposure and attention deficit hyperactivity disorder (ADHD) symptoms in children at 6-12 years of age in Mexico City. Environ. Int. 2018, 121, 658-666. [CrossRef]

280. Dugrillon, A. Iodolactones and iodoaldehydes-mediators of iodine in thyroid autoregulation. Exp Clin. Endocrinol. Diabetes 1996, 104, 41-45. [CrossRef] [PubMed]

281. Beukelman, C.; van den Berg, A.J.; Hoekstra, M.J.; Uhl, R.; Reimer, K.; Mueller, S. Anti-inflammatory properties of a liposomal hydrogel with povidone-iodine (Repithel) for wound healing in vitro. Burns 2008, 34, 845-855. [CrossRef] [PubMed]

282. Moore, K.; Thomas, A.; Harding, K. Iodine released from the wound dressing Iodosorb modulates the secretion of cytokines by human macrophages responding to bacterial lipopolysaccharide. Int. J. Biochem. Cell Biol. 1997, 29, 163-171. [CrossRef]

283. Nyska, A.; Lomnitski, L.; Maronpot, R.; Moomaw, C.; Brodsky, B.; Sintov, A.; Wormser, U. Effects of iodine on inducible nitric oxide synthase and cyclooxygenase-2 expression in sulfur mustard-induced skin injury in guinea pigs. Arch. Toxicol. 2001, 74, 768-774. [CrossRef]

284. Venturi, S.; Venturi, M. Iodide, thyroid and stomach carcinogenesis: Evolutionary story of a primitive antioxidant? Eur. J. Endocrinol. 1999, 140, 371-372. [CrossRef]

285. Winkler, R.; Griebenow, S.; Wonisch, W. Effect of iodide on total antioxidant status of human serum. Cell Biochem. Funct. 2000, 18, 143-146. [CrossRef]

286. Smyth, P.P. Role of iodine in antioxidant defence in thyroid and breast disease. Biofactors 2003, 19, 121-130. [CrossRef]

287. Garcia-Solis, P.; Alfaro, Y.; Anguiano, B.; Delgado, G.; Guzman, R.C.; Nandi, S.; Díaz-Muñoz, M.; Vázquez-Martínez, O.; Aceves, C. Inhibition of $N$-methyl- $N$-nitrosourea-induced mammary carcinogenesis by molecular iodine (I2) but not by iodide (I-) treatment Evidencethat (I2) prevents cancer promotion. Mol. Cell. Endocrinol. 2005, 236, 49-57. [CrossRef] [PubMed]

288. Klebanoff, S.J. The iron- $\mathrm{H}_{2} \mathrm{O}_{2}$-iodide cytotoxic system. J. Exp. Med. 1982, 156, 1262-1267. [CrossRef] [PubMed]

289. Majerus, P.M.; Courtois, P.A. Susceptibility of Candida albicans toperoxidase-catalyzed oxidation products of thiocyanate, iodide and bromide. J. Biol. Buccale 1992, 20, 241-245. [PubMed]

290. Cann, S.A.; van Netten, J.P.; Glover, D.W.; van Netten, C. Iodide accumulation in extrathyroidal tissues. J. Clin. Endocrinol. Metab. 1999, 84, 821-822. [CrossRef]

291. Bosch, E.H.; van Doorne, H.; de Vries, S. The lactoperoxidase system: The influence of iodide and the chemical and antimicrobial stability over the period of about 18 months. J. Appl. Microb. 2000, 89, 215-224. [CrossRef]

292. Ihalin, R.; Loimaranta, V.; Tenovuo, J. Origin, structure, and biological activities of peroxidases in human saliva. Arch. Biochem. Biophys. 2006, 445, 261-268. [CrossRef]

293. Huang, Y.Y.; Choi, H.; Kushida, Y.; Bhayana, B.; Wang, Y.; Hamblin, M.R. Broad-spectrum antimicrobial effects of photocatalysis using titanium dioxide nanoparticles are strongly potentiated by addition of potassium iodide. Antimicrob. Agents Chemother. 2016, 60, 5445-5453. [CrossRef]

294. Fischer, A.J.; Lennemann, N.J.; Krishnamurthy, S.; Pócza, P.; Durairaj, L.; Launspach, J.L.; Rhein, B.A.; Wohlford-Lenane, C.; Lorentzen, D.; Bánfi, B.; et al. Enhancement of respiratory mucosal anti-viral defenses by iodide oxidation. Am. J. Respir. Cell Mol. Biol. 2011, 45, 874-881. [CrossRef] [PubMed]

295. Kargar, S.; Shiryazdi, S.M.; Atashi, S.R.; Neamatzadeh, H.; Kamali, M. Urinary Iodine Concentrations in Cancer Patients. Asian Pac. J. Cancer Prev. 2017, 18, 819-821.

296. Cann, S.A.; van Netten, J.P.; van Netten, C. Iodine, selenium and the development of breast cancer. Cancer Causes Control 2000, 11, 121-127. [CrossRef] [PubMed]

297. Rappaport, J. Changes in Dietary Iodine Explains Increasing Incidence of Breast Cancer with Distant Involvement in Young Women. J. Cancer 2017, 8, 174-177. [CrossRef] [PubMed]

298. Eskin, B.A. Iodine metabolism and breast cancer. Trans. N. Y. Acad. Sci. 1970, 32, 911-947. [CrossRef]

299. Stadel, B.V. Dietary iodine and risk of breast, endometrial, and ovarian cancer. Lancet 1976, 307, 890-891. [CrossRef]

300. Franceschi, S. Iodine intake and thyroid carcinoma-A potential risk factor. Exp. Clin. Endocrinol. Diabetes 1998, 106, 38-44. [CrossRef]

301. Feldt-Rasmussen, U. Iodine and cancer. Thyroid 2001, 11, 483-486. [CrossRef] 
302. Ohshima, M.; Ward, J.M. Dietary iodine deficiency as a tumor promoter and carcinogen in male F344/NCr rats. Cancer Res. 1986, 46, 877-883. [PubMed]

303. Fang, W.T.; Qao, B.S.; Wang, J.B. Iodine deficiency induces thyroid cancer in rats and mice. Zhonghua Zhong Liu Za Zhi 1994, 16, 341-344.

304. Zimmermann, M.; Galetti, V. Iodine intake as a risk factor for thyroid cancer: A comprehensive review of animal and human studies. Thyroid Res. 2015, 8, 8. [CrossRef] [PubMed]

305. Ward, J.M.; Ohshima, M. The role of iodine in carcinogenesis. Adv. Exp. Med. Biol. 1986, 206, 529-542.

306. Mitro, S.D.; Rozek, L.S.; Vatanasapt, P.; Suwanrungruang, K.; Chitapanarux, I.; Srisukho, S.; Sriplung, H.; Meza, R. Iodine deficiency and thyroid cancer trends in three regions of Thailand, 1990-2009. Cancer Epidemiol. 2016, 43, 92-99. [CrossRef] [PubMed]

307. Hoption Cann, S.A.; Qiu, Z.; van Netten, C. A prospective study of iodine status, thyroid function, and prostate cancer risk: Follow-up of the First National Health and Nutrition Examination Survey. Nutr. Cancer 2007, 58, 28-34. [CrossRef]

308. Allen, N.E.; Sauvaget, C.; Roddam, A.W.; Appleby, P.; Nagano, J.; Suzuki, G.; Key, T.J.; Koyama, K. A prospective study of diet and prostate cancer in Japanese men. Cancer Causes Control 2004, 15, 911-920. [CrossRef]

309. Aranda, N.; Sosa, S.; Delgado, G.; Aceves, C.; Anguiano, B. Uptake and antitumoral effects of iodine and 6-iodolactone in differentiated and undifferentiated human prostate cancer cell lines. Prostate 2013, 73, 31-41. [CrossRef]

310. Aceves, C.; Anguiano, B. Is Iodine an Anti-oxidant and Antiproliferative Agent for the Mammary and Prostate Glands? In Comprehensive Handbook of Iodine: Nutritional, Endocrine and Pathological Aspects; Preedy, V.R., Burrow, G.N., Watson, R.R., Eds.; Academic Press (Elsevier): London, UK, 2009; pp. 249-257.

311. Aceves, C.; García-Solís, P.; Arroyo-Helguera, O.; Vega-Riveroll, L.; Delgado, G.; Anguiano, B. Antineoplastic effect of iodine in mammary cancer: Participation of 6-iodolactone (6-IL) and peroxisome proliferator-activated receptors (PPAR). Mol. Cancer 2009, 8, 33. [CrossRef]

312. Mendieta, I.; Nunez-Anita, E.; Delgado, G.; Aceves, C. Differential effect of iodine on the implantation and metastatic potential of xenografts from two different human breast cancer cell lines. Cancer Res. 2011, 71 (Suppl. 8), 4224. [CrossRef]

313. Bray, F.; Ferlay, J.; Soerjomataram, I.; Siegel, R.L.; Torre, L.A.; Jemal, A. Global cancer statistics 2018: GLOBOCAN estimates of incidence and mortality worldwide for 36 cancers in 185 countries. CA Cancer J. Clin. 2018, 68, 394-424. [CrossRef]

314. World Cancer Research Fund; American Institute for Cancer Research. Global Cancer Data by Country. Available online: https://www.wcrf.org/dietandcancer/cancer-trends/data-cancer-frequency-country (accessed on 22 January 2019).

315. Carretero, J.; Sánchez-Robledo, V.; Carretero-Hernández, M.; Catalano-Iniesta, L.; García-Barrado, M.J.; Iglesias-Osma, M.C.; Blanco, E.J. Prolactin system in the hippocampus. Cell Tissue Res. 2019, 375, 193-199. [CrossRef]

316. Benker, G.; Jaspers, C.; Hausler, G.; Reinwein, D. Control of prolactin secretion. Klinische Wochenschrift. 1990, 68, 1157-1167. [CrossRef]

317. Larsen, C.M.; Grattan, D.R. Prolactin, neurogenesis, and maternal behaviors. Brain Behav. Immun. 2012, 26, 201-209. [CrossRef]

318. Ferraris, J.; Bernichtein, S.; Pisera, D.; Goffin, V. Use of prolactin receptor antagonist to better understand prolactin regulation of pituitary homeostasis. Neuroendocrinology 2013, 98, 171-179. [CrossRef]

319. Patil, M.J.; Henry, M.A.; Akopian, A.N. Prolactin receptor in regulation of neuronal excitability and channels. Channels 2014, 8, 193-202. [CrossRef]

320. Reyes-Mendoza, J.; Morales, T. Post-treatment with prolactin protects hippocampal CA1 neurons of the ovariectomized female rat against kainic acid-induced neurodegeneration. Neuroscience 2016, 328, 58-68. [CrossRef]

321. Morales, T. Recent findings on neuroprotection against excitotoxicity in the hippocampus of female rats. J. Neuroendocrinol. 2011, 23, 994-1001. [CrossRef]

322. Tejadilla, D.; Cerbón, M.; Morales, T. Prolactin reduces the damaging effects of excitotoxicity in the dorsal hippocampus of the female rat independently of ovarian hormones. Neuroscience 2010, 169, 1178-1185. [CrossRef] 
323. Morales, T.; Lorenson, M.; Walker, A.M. Both prolactin (PRL) and a molecular mimic of phosphorylated PRL, S179D-PRL, protect the hippocampus of female rats against excitotoxicity. Neuroscience 2014, 258, 211-217. [CrossRef]

324. Torner, L.; Karg, S.; Blume, A.; Kandasamy, M.; Kuhn, H.G.; Winkler, J.; Aigner, L.; Neumann, I.D. Prolactin prevents chronic stress-induced decrease of adult hippocampal neurogenesis and promotes neuronal fate. J. Neurosci. 2009, 29, 1826-1833. [CrossRef]

325. Cabrera, V.; Cantú, D.; Ramos, E.; Vanoye-Carlo, A.; Cerbón, M.; Morales, T. Lactation is a natural model of hippocampus neuroprotection against excitotoxicity. Neurosci. Lett. 2009, 461, 136-139. [CrossRef]

326. Vergara-Castañeda, E.; Grattan, D.R.; Pasantes-Morales, H.; Pérez-Domínguez, M.; Cabrera-Reyes, E.A.; Morales, T.; Cerbón, M. Prolactin mediates neuroprotection against excitotoxicity in primarycell cultures of hippocampal neurons via its receptor. Brain Res. 2016, 1636, 193-199. [CrossRef]

327. Walker, T.L.; Vukovic, J.; Koudijs, M.M.; Blackmore, D.G.; Mackay, E.W.; Sykes, A.M.; Overall, R.W.; Hamlin, A.S.; Bartlett, P.F. Prolactin stimulates precursor cells in the adult mouse hippocampus. PLoS ONE 2012, 7, e44371. [CrossRef]

328. Rivero-Segura, N.A.; Flores-Soto, E.; García de la Cadena, S.; Coronado-Mares, I.; Gómez-Verjan, J.C.; Ferreira, D.G.; Cabrera-Reyes, E.A.; Lopes, L.V.; Massieu, L.; Cerbón, M. Prolactin-induced neuro-protection against glutamate excitotoxicity is mediated by the reduction of $\left[\mathrm{Ca}^{2+}\right]$ i overload and NF- $\mathrm{kB}$ activation. PLoS ONE 2017, 12, e0176910. [CrossRef]

329. Kinsley, C.H.; Trainer, R.; Stafisso-Sandoz, G.; Quadros, P.; Marcus, L.K.; Hearon, C.; Meyer, E.A.; Hester, N.; Morgan, M.; Kozub, F.J.; et al. Motherhood and the hormones of pregnancy modify concentrations of hippocampal neuronal dendritic spines. Horm. Behav. 2006, 49, 131-142. [CrossRef]

330. Brusco, J.; Wittmann, R.; de Azevedo, M.; Lcion, A.; Franci, C.; Giovenardi, M.; Rasia-Filho, A.A. Plasma hormonal profiles and dendritic spines density and morphology in the hippocampal CA1 stratum radiatum, evidenced by light microscopy, of virgin and postpartum female rats. Neurosci. Lett. 2008, 438, 346-350. [CrossRef]

331. Infant and Young Child Feeding: Model Chapter for Textbooks for Medical Students and Allied Health Professionals; SESSION 2, The Physiological Basis of Breastfeeding; World Health Organization: Geneva, Switzerland, 2009. Available online: https:/ / www.ncbi.nlm.nih.gov/books/NBK148970/ (accessed on 19 January 2019).

332. Balbach, L.; Wallaschofski, H.; Volzke, H.; Nauck, M.; Dorr, M.; Haring, R. Serum prolactin concentrations as risk factor of metabolic syndrome or type 2 diabetes? BMC Endocr. Disord. 2013, 13, 12. [CrossRef] [PubMed]

333. Wang, T.; Xu, Y.; Xu, M.; Ning, G.; Lu, J.; Dai, M.; Xu, B.; Sun, J.; Sun, W.; Lai, S.; et al. Circulating Prolactin and Risk of Type 2 Diabetes: A Prospective Study. Am. J. Epidemiol. 2015, 184, 295-301. [CrossRef]

334. Zheng, Y.; Ley, S.H.; Hu, F.B. Global aetiology and epidemiology of type 2 diabetes mellitus and its complications. Nat. Rev. Endocrinol. 2018, 14, 88-98. [CrossRef]

335. Corona, G.; Mannucci, E.; Jannini, E.A.; Lotti, F.; Ricca, V.; Monami, M.; Boddi, V.; Bandini, E.; Balercia, G.; Forti, G.; et al. Hypoprolactinemia: A new clinical syndrome in patients with sexual dysfunction. J. Sex. Med. 2009, 6, 1457-1466. [CrossRef]

336. Rutter, M.K.; Maggi, M.; EMAS Study Group. Low prolactin is associated with sexual dysfunction and psychological or metabolic disturbances in middle aged and elderly men: The European Male Aging Study (EMAS). J. Sex. Med. 2014, 11, 240-253.

337. Corona, G.; Rastrelli, G.; Boddi, V.; Monami, M.; Melani, C.; Balzi, D.; Sforza, A.; Forti, G.; Mannucci, E.; Maggi, M. Prolactin levels independently predict major cardiovascular events in patients with erectile dysfunction. Int. J. Androl. 2011, 34, 217-224. [CrossRef]

(C) 2019 by the author. Licensee MDPI, Basel, Switzerland. This article is an open access article distributed under the terms and conditions of the Creative Commons Attribution (CC BY) license (http://creativecommons.org/licenses/by/4.0/). 